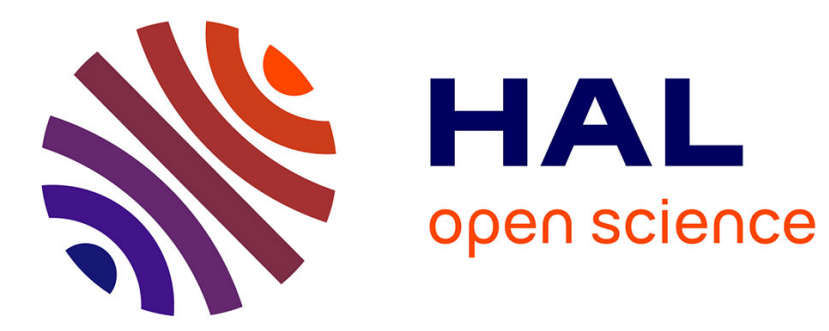

\title{
Dipicolylamine styryldiazine derivatives: Synthesis and photophysical studies
}

\author{
Sylvain Achelle, Julian Rodriguez-Lopez, Filip Bures, Francoise Robin-Le
}

Guen

\section{- To cite this version:}

Sylvain Achelle, Julian Rodriguez-Lopez, Filip Bures, Francoise Robin-Le Guen. Dipicolylamine styryldiazine derivatives: Synthesis and photophysical studies. Dyes and Pigments, 2015, 121, pp.305311. 10.1016/j.dyepig.2015.05.026 . hal-01166771

\section{HAL Id: hal-01166771}

\section{https://hal-univ-rennes1.archives-ouvertes.fr/hal-01166771}

Submitted on 12 Nov 2015

HAL is a multi-disciplinary open access archive for the deposit and dissemination of scientific research documents, whether they are published or not. The documents may come from teaching and research institutions in France or abroad, or from public or private research centers.
L'archive ouverte pluridisciplinaire HAL, est destinée au dépôt et à la diffusion de documents scientifiques de niveau recherche, publiés ou non, émanant des établissements d'enseignement et de recherche français ou étrangers, des laboratoires publics ou privés. 


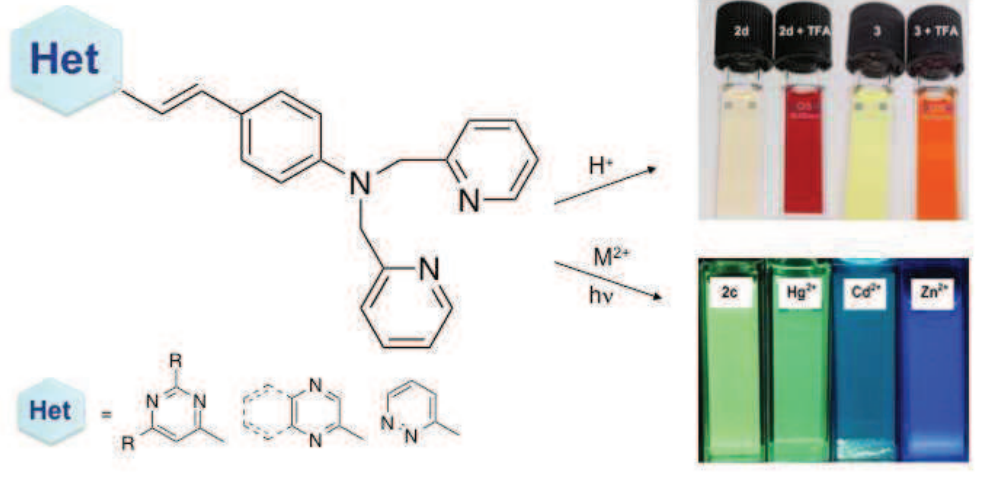




\title{
Dipicolylamine Styryldiazine Derivatives: Synthesis and Photophysical Studies.
}

Sylvain Achelle ${ }^{\mathrm{a}, *}$, Julián Rodríguez-López*, ${ }^{*}$, Filip Burešc , and Françoise Robin-le Guen ${ }^{\mathrm{a}}$

${ }^{a}$ Institut des Sciences Chimiques de Rennes UMR CNRS 6226, IUT de Lannion, rue Edouard Branly, BP 30219, F22302 Lannion Cedex, France.

${ }^{\mathrm{b}}$ Facultad de Ciencias y Tecnologías Químicas, Universidad de Castilla-La Mancha, 13071 Ciudad Real, Spain.

${ }^{\mathrm{c}}$ Institute of Organic Chemistry and Technology, Faculty of Chemical Technology, University of Pardubice, Studentská 573, Pardubice 53210, Czech Republic

Corresponding authors: *E-mail: sylvain.achelle@univ-rennes1.fr tel: +33 (0)296 469 448; julian.rodriguez@uclm.es tel: +34926295300

\begin{abstract}
Different D- $\pi$-A push-pull molecules in which dipicolylamine (DPA) is used as the donor group, different diazines as the acceptor groups, and styryl as the $\pi$-conjugated spacer have been synthesized in a straightforward manner by aldol condensation of 4-(di-2picolylamino)benzaldehyde and the appropriate methyldiazine. All of the compounds showed $\pi-\pi^{*}$ transitions in the UV or visible region and the emission of yellow-green light upon irradiation. Significant red shifts were observed in the fluorescence emission maxima of these compounds on increasing the solvent polarity, a finding that suggests the formation of an intramolecular charge-separated emitting state that is also supported by semi-empirical
\end{abstract}


calculations. In some cases, protonation led to marked color changes, thus showing the ability of these molecules to function as colorimetric $\mathrm{pH}$ sensors. The DPA and diazine units can act as coordination sites for metal cations such as $\mathrm{Zn}^{2+}, \mathrm{Cd}^{2+}$ or $\mathrm{Hg}^{2+}$, leading to a blue or red shift in the fluorescence spectra due to the change in the intramolecular charge transfer properties. This phenomenon could become a powerful tool for the creation of multiple emission colors with a single molecule after suitable design.

Keywords: diazines; metal cations; fluorescence; intramolecular charge transfer; $\pi$ conjugated systems

\section{Introduction}

During the past decade, donor- $\pi$-acceptor (D- $\pi$-A) push-pull systems that incorporate diazine rings as electron-attracting units have been widely studied for their luminescence and non-linear optical properties [1]. The fluorescence of these molecules relies heavily on the nature of the donor and acceptor parts, and it can be easily modulated by several external stimuli. For example, diazine derivatives have been developed as fluorescent sensors for polarity [2], pH [2a,c,e,3], metal cations [4], proteins [5] and particular forms of DNA [6]. Most recently, 1,3-benzodiazine (quinazoline) units were used as electron-deficient segments in D- $\pi$-A dyes that displayed solid-state white photoluminescence (PL) and electroluminescence (EL) by doping a certain amount of acid into thin films, which has a potential application in the fabrication of white organic light emitting diodes (OLEDs) [7].

In general, D- $\pi$-A push-pull systems are highly sensitive to metal coordination, which can occur not only in the acceptor part of the molecule but also in the donor part [8]. Binding in the A unit leads to a red shift in the emission spectra due to stronger stabilization of the LUMO than the HOMO, which results in a lower HOMO-LUMO energy gap. In contrast, interaction with the $\mathrm{D}$ unit results a blue shift of the fluorescence because the metal coordination stabilizes the HOMO more strongly than the LUMO. Of particular interest are 
molecules that possess metal-binding sites on both the electron-donor and -acceptor parts because such systems can show multiple fluorescence colors in response to several metal cation inputs [9]. In this context, Shiraishi et al. described a styrylquinoline dye with a dipicolylamine (DPA) moiety that showed multicolor fluorescence upon addition of different metal cations. For the first time, near white fluorescence was created by the addition of a mixture of $\mathrm{Cd}^{2+}$ and $\mathrm{Pb}^{2+}$ in an appropriate ratio [8a].

The diazine ring is an excellent candidate to be incorporated in such structures because of its high electron-withdrawing character and potential ligand properties. Thus, taking advantage of our experience in the synthesis of arylvinyl (styryl) diazines and benzodiazines $[2 a-b, e, 6 a, 10]$, we report here the straightforward preparation of a series of D- $\pi$-A push-pull molecules in which DPA is used as a donor group and different diazine-based groups [pyridazine, pyrimidine, pyrazine, quinoxaline and di(pyridin-2-yl)pyrimidine] are used as acceptors. The DPA group is a strong electron donor that can act as a coordination site for metal cations and this unit has been widely used for the design of new fluorophores [8a,11]. On the other hand, we previously showed that 4-arylvinyl-2,6-di(pyridyn-2-yl)pyrimidines can coordinate various metal cations, such as $\mathrm{Zn}^{2+}, \mathrm{Sn}^{2+}$ and $\mathrm{Ca}^{2+}$, to give a red-shifted emission [12].

The photophysical properties of the prepared compounds are also reported, including solvatochromism and the effect that treatment with acid and selected metal cations $\left(\mathrm{Zn}^{2+}\right.$, $\mathrm{Cd}^{2+}, \mathrm{Hg}^{2+}$ ) has on the luminescence properties.

\section{Experimental}

\subsection{General.}

4-(Di-2-picolylamino)benzaldehyde (1) [13] and 4-methyl-2,6-dipyridin-2-yl-pyrimidine [10e] were obtained as described previously. In air- and moisture-sensitive reactions, all glassware was flame-dried and cooled under nitrogen. NMR spectra were acquired at room 
temperature on a Bruker AC-300 spectrometer. Chemical shifts are given in parts per million relative to TMS $\left({ }^{1} \mathrm{H}, 0.0 \mathrm{ppm}\right)$ and $\mathrm{CDCl}_{3}\left({ }^{13} \mathrm{C}, 77.0 \mathrm{ppm}\right)$. Acidic impurities in $\mathrm{CDCl}_{3}$ were removed by treatment with anhydrous $\mathrm{K}_{2} \mathrm{CO}_{3}$. High resolution mass analyses were performed at the "Centre Regional de Mesures Physiques de l'Ouest" (CRMPO, University of Rennes1) using a Bruker MicroTOF-Q II apparatus. UV/vis spectra were recorded on a Jasco V-530 spectrophotometer using standard $1 \mathrm{~cm}$ quartz UV cells. Fluorescence spectra were recorded on a Jasco FP-750 spectrofluorimeter. Compounds were excited at their absorption maxima (band of lowest energy) to record the emission spectra. The $\Phi_{\mathrm{F}}$ values were calculated using a well-known procedure with two different standards, quinine sulfate in $0.1 \mathrm{M} \mathrm{H}_{2} \mathrm{SO}_{4}$ and 9,10-diphenylanthracene in cyclohexane [14]. Stokes shifts were calculated by considering the lowest energetic absorption band.

\subsection{General Procedure for the synthesis of arylvinyldiazine (styryldiazines).}

4-(Di-2-picolylamino)benzaldehyde (1) $(110 \mathrm{mg}, 0.36 \mathrm{mmol})$ and the appropriate methyldiazine derivative $(0.72 \mathrm{mmol} ; 0.36 \mathrm{mmol}$ for 4-methyl-2,6-dipyridin-2-yl-pyrimidine; $0.18 \mathrm{mmol}$ for 4,6-dimethylpyrimidine) were dissolved in anhydrous THF $(15 \mathrm{~mL}) . \mathrm{K}^{\mathrm{t}} \mathrm{BuO}$ (1.44 mmol, $161 \mathrm{mg}, 4$ eq.) was slowly added at room temperature and the solution was heated under reflux for $15 \mathrm{~h}$. The mixture was allowed to cool and water was added. THF was evaporated and the mixture was extracted with $\mathrm{CH}_{2} \mathrm{Cl}_{2}$. The organic layer was dried over $\mathrm{MgSO}_{4}$ and the solvent was removed under vacuum. The crude product was purified by flash chromatography.

\subsubsection{4-[2-(4-Di-2-picolylaminophenyl)vinyl]pyrimidine $2 a$}

The crude product was purified by flash chromatography (alumina, eluent: petroleum ether/ethyl acetate 1:1). Orange solid: 61\% (82 mg). Mp: $144-145{ }^{\circ} \mathrm{C} .{ }^{1} \mathrm{H}$ NMR $(300 \mathrm{MHz}$, $\left.\mathrm{CDCl}_{3}\right): \delta 4.87(\mathrm{~s}, 4 \mathrm{H}), 6.73(\mathrm{~d}, 2 \mathrm{H}, J=8.7 \mathrm{~Hz}), 6.81(\mathrm{~d}, 1 \mathrm{H}, J=15.9 \mathrm{~Hz}), 7.20(\mathrm{~d}, 1 \mathrm{H}, J=$ $2.1 \mathrm{~Hz}), 7.25-7.23(\mathrm{~m}, 4 \mathrm{H}), 7.42(\mathrm{~d}, 2 \mathrm{H}, J=8.7 \mathrm{~Hz}), 7.67-7.61(\mathrm{~m}, 2 \mathrm{H}), 7.76(\mathrm{~d}, 1 \mathrm{H}, J=15.9$ 
$\mathrm{Hz}), 8.63-8.56(\mathrm{~m}, 3 \mathrm{H}), 9.07(\mathrm{~s}, 1 \mathrm{H}) .{ }^{13} \mathrm{C} \mathrm{NMR}$ and JMOD (75 MHz, $\left.\mathrm{CDCl}_{3}\right): \delta 162.9(\mathrm{C})$, $158.1(\mathrm{C}), 156.8(\mathrm{CH}), 149.81(\mathrm{CH}), 149.76(\mathrm{CH}), 149.4(\mathrm{C}), 137.5(\mathrm{CH}), 136.9(\mathrm{CH}), 129.4$ (CH), $124.7(\mathrm{C}), 122.3(\mathrm{CH}), 121.2(\mathrm{CH}), 120.8(\mathrm{CH}), 118.0(\mathrm{CH}), 112.7(\mathrm{CH}), 57.2\left(\mathrm{CH}_{2}\right)$. HRMS (ESI/ASAP): $m / z$ calculated for $\mathrm{C}_{24} \mathrm{H}_{22} \mathrm{~N}_{5}[\mathrm{M}+\mathrm{H}]^{+} 380.1875$, found 380.1882 .

\subsubsection{4-[2-(4-Di-2-picolylaminophenyl)vinyl]-2,6-dipyridin-2-yl-pyrimidine $\mathbf{2 b}$}

The crude product was purified by flash chromatography (alumina, eluent: ethyl acetate/isopropanol 9:1) followed by crystallization from $\mathrm{CH}_{2} \mathrm{Cl}_{2} / n$-heptane. Orange solid: 64\% (123 mg). Mp: $84-86{ }^{\circ} \mathrm{C} .{ }^{1} \mathrm{H}$ NMR $\left(300 \mathrm{MHz}, \mathrm{CDCl}_{3}\right): \delta 4.90(\mathrm{~s}, 4 \mathrm{H}), 6.75(\mathrm{~d}, 2 \mathrm{H}, J=$ $8.4 \mathrm{~Hz}), 7.26-7.17(\mathrm{~m}, 5 \mathrm{H}), 7.43(\mathrm{t}, 2 \mathrm{H}, J=6.0 \mathrm{~Hz}), 7.51(\mathrm{~d}, 2 \mathrm{H}, J=8.4 \mathrm{~Hz}), 7.67(\mathrm{t}, 2 \mathrm{H}, J=$ 7.5 Hz), 7.97-7.88 (m, 3H), $8.44(\mathrm{~s}, 1 \mathrm{H}), 8.64-8.62(\mathrm{~m}, 2 \mathrm{H}), 8.77-8.67(\mathrm{~m}, 3 \mathrm{H}), 8.90(\mathrm{~d}, 1 \mathrm{H}$, $J=4.2 \mathrm{~Hz}) .{ }^{13} \mathrm{C}$ NMR and JMOD (75 MHz, $\left.\mathrm{CDCl}_{3}\right): \delta 165.6(\mathrm{C}), 163.4(\mathrm{C}), 163.0(\mathrm{C}), 158.2$ (C), $155.6(\mathrm{C}), 154.5(\mathrm{C}), 150.0(\mathrm{CH}), 149.8(\mathrm{CH}), 149.4(\mathrm{CH}), 149.3(\mathrm{C}), 137.6(\mathrm{CH}), 137.0$ (CH), $136.9(\mathrm{CH}), 136.8(\mathrm{CH}), 129.4(\mathrm{CH}), 125.2(\mathrm{CH}), 125.2(\mathrm{C}), 124.5(\mathrm{CH}), 123.9(\mathrm{CH})$, $122.8(\mathrm{CH}), 122.2(\mathrm{CH}), 122.1(\mathrm{CH}), 120.8(\mathrm{CH}), 112.6(\mathrm{CH}), 112.2(\mathrm{CH}), 57.2\left(\mathrm{CH}_{2}\right)$. HRMS (ESI/ASAP): $m / z$ calculated for $\mathrm{C}_{34} \mathrm{H}_{28} \mathrm{~N}_{7}[\mathrm{M}+\mathrm{H}]^{+}$534.2406, found 534.2413.

\subsubsection{2-[2-(4-Di-2-picolylaminophenyl)vinyl]pyrazine $2 c$}

The crude product was purified by flash chromatography (alumina, eluent: petroleum ether/ethyl acetate 1:1). Yellow solid: 63\% (85 mg). Mp: $150-151{ }^{\circ} \mathrm{C} .{ }^{1} \mathrm{H}$ NMR $(300 \mathrm{MHz}$, $\left.\mathrm{CDCl}_{3}\right): \delta 4.87(\mathrm{~s}, 4 \mathrm{H}), 6.72(\mathrm{~d}, 2 \mathrm{H}, J=8.7 \mathrm{~Hz}), 6.91(\mathrm{~d}, 1 \mathrm{H}, J=15.9 \mathrm{~Hz}), 7.24-7.17(\mathrm{~m}$, 4H), $7.42(\mathrm{~d}, 2 \mathrm{H}, J=8.7 \mathrm{~Hz}), 7.65-7.59(\mathrm{~m}, 3 \mathrm{H}), 8.31(\mathrm{~d}, 1 \mathrm{H}, J=2.4 \mathrm{~Hz}), 8.46(\mathrm{~d}, 1 \mathrm{H}, J=$ $2.4 \mathrm{~Hz}), 8.55(\mathrm{~s}, 1 \mathrm{H}), 8.62-8.60(\mathrm{~m}, 2 \mathrm{H}) .{ }^{13} \mathrm{C} \mathrm{NMR}$ and JMOD (75 MHz, $\left.\mathrm{CDCl}_{3}\right): \delta 158.3$ (C), $149.8(\mathrm{CH}), 149.0(\mathrm{C}), 144.1(\mathrm{CH}), 143.4(\mathrm{CH}), 142.0(\mathrm{C}), 141.4(\mathrm{CH}), 136.9(\mathrm{CH})$, $135.1(\mathrm{CH}), 128.8(\mathrm{C}), 125.3(\mathrm{CH}), 122.2(\mathrm{CH}), 120.8(\mathrm{CH}), 119.9(\mathrm{CH}), 112.7(\mathrm{CH}), 57.3$ $\left(\mathrm{CH}_{2}\right)$. HRMS (ESI/ASAP): $m / z$ calculated for $\mathrm{C}_{25} \mathrm{H}_{22} \mathrm{~N}_{5}[\mathrm{M}+\mathrm{H}]^{+} 380.1875$, found 380.1880. 


\subsubsection{2-[2-(4-Di-2-picolylaminophenyl)vinyl] quinoxaline $2 \boldsymbol{d}$}

The crude product was purified by flash chromatography (alumina, eluent: petroleum ether/ethyl acetate 1:1). Yellow solid: 84\% (129 mg). Mp 112-113 ${ }^{\circ} \mathrm{C} .{ }^{1} \mathrm{H}$ NMR $(300 \mathrm{MHz}$, $\left.\mathrm{CDCl}_{3}\right): \delta 4.88(\mathrm{~s}, 4 \mathrm{H}), 6.75(\mathrm{~d}, 2 \mathrm{H}, J=8.7 \mathrm{~Hz}), 7.13(\mathrm{~d}, 1 \mathrm{H}, J=15.9 \mathrm{~Hz}), 7.21-7.18(\mathrm{~m}$, 2H), 7.27-7.24 (m, 2H), $7.48(\mathrm{~d}, 2 \mathrm{H}, J=8.7 \mathrm{~Hz}), 7.68-7.62(\mathrm{~m}, 4 \mathrm{H}), 7.75(\mathrm{~d}, 1 \mathrm{H}, J=15.9$ $\mathrm{Hz}), 8.03-7.99(\mathrm{~m}, 2 \mathrm{H}), 8.62-8.60(\mathrm{~m}, 2 \mathrm{H}), 8.97(\mathrm{~s}, 1 \mathrm{H}) .{ }^{13} \mathrm{C}$ NMR and JMOD $(75 \mathrm{MHz}$, $\left.\mathrm{CDCl}_{3}\right): \delta 158.2(\mathrm{C}), 151.4(\mathrm{C}), 149.9(\mathrm{CH}), 149.2(\mathrm{CH}), 144.5(\mathrm{CH}), 142.6(\mathrm{C}), 141.2(\mathrm{C})$, $136.9(\mathrm{CH}), 136.4(\mathrm{CH}), 130.1(\mathrm{CH}), 129.1(\mathrm{CH}), 128.9(\mathrm{CH}), 128.6(\mathrm{CH}), 125.3(\mathrm{C}), 122.2$ (CH), $121.2(\mathrm{CH}), 120.8(\mathrm{CH}), 112.7(\mathrm{CH}), 57.2\left(\mathrm{CH}_{2}\right)$. HRMS (ESI/ASAP): $m / z$ calculated for $\mathrm{C}_{28} \mathrm{H}_{23} \mathrm{~N}_{5} \mathrm{Na}[\mathrm{M}+\mathrm{Na}]^{+} 452.1851$, found 452.1851 .

\subsubsection{3-[2-(4-Di-2-picolylaminophenyl)vinyl]pyridazine $2 \boldsymbol{e}$}

The crude product was purified by flash chromatography (alumina, eluent: petroleum ether/ethyl acetate 1:1). Yellow solid: 64\% (86 mg). Mp: 171-172 ${ }^{\circ} \mathrm{C} .{ }^{1} \mathrm{H}$ NMR $(300 \mathrm{MHz}$, $\left.\mathrm{CDCl}_{3}\right): \delta 4.88(\mathrm{~s}, 4 \mathrm{H}), 6.74(\mathrm{~d}, 2 \mathrm{H}, J=8.7 \mathrm{~Hz}), 7.13(\mathrm{~d}, 1 \mathrm{H}, J=16.2 \mathrm{~Hz}), 7.22-7.18(\mathrm{~m}$, 2H), $7.37\left(\mathrm{dd}, 1 \mathrm{H}, J_{1}=4.8 \mathrm{~Hz}, J_{2}=8.7 \mathrm{~Hz}\right), 7.44(\mathrm{~d}, 2 \mathrm{H}, J=8.7 \mathrm{~Hz}), 7.59-7.54(\mathrm{~m}, 2 \mathrm{H})$, $7.68-7.62(\mathrm{~m}, 2 \mathrm{H}), 8.62-8.61(\mathrm{~m}, 2 \mathrm{H}), 8.97\left(\mathrm{dd}, 1 \mathrm{H}, J_{1}=1.5 \mathrm{~Hz}, J_{2}=4.8 \mathrm{~Hz}\right) .{ }^{13} \mathrm{C} \mathrm{NMR}$ and JMOD (75 MHz, $\left.\mathrm{CDCl}_{3}\right): \delta 159.0(\mathrm{C}), 158.9(\mathrm{C}), 158.3(\mathrm{C}), 149.8(\mathrm{CH}), 148.5(\mathrm{CH}), 136.9$ $(\mathrm{CH}), 135.0(\mathrm{C}), 128.9(\mathrm{CH}), 126.2(\mathrm{CH}), 125.2(\mathrm{C}), 123.4(\mathrm{CH}), 122.2(\mathrm{CH}), 121.0(\mathrm{CH})$, $120.8(\mathrm{CH}), 112.7(\mathrm{CH}), 57.3\left(\mathrm{CH}_{2}\right)$. HRMS (ESI/ASAP): $m / z$ calculated for $\mathrm{C}_{24} \mathrm{H}_{22} \mathrm{~N}_{5}[\mathrm{M}+$ $\mathrm{H}]^{+} 380.1875$, found 380.1879 .

\subsubsection{4,6-Bis[2-(4-di-2-picolylaminophenyl)vinyl]pyrimidine 3}

The crude product was purified by flash chromatography (alumina, eluent: petroleum ether/ethyl acetate 1:1). Orange solid: 52\% (64 mg). Mp: 110-112 ${ }^{\circ} \mathrm{C} .{ }^{1} \mathrm{H}$ NMR $(300 \mathrm{MHz}$, $\left.\mathrm{CDCl}_{3}\right): \delta 4.87(\mathrm{~s}, 8 \mathrm{H}), 6.72(\mathrm{~d}, 4 \mathrm{H}, J=8.7 \mathrm{~Hz}), 6.80(\mathrm{~d}, 2 \mathrm{H}, J=15.9 \mathrm{~Hz}), 7.10(\mathrm{~s}, 1 \mathrm{H}), 7.22-$ 
$7.18(\mathrm{~m}, 8 \mathrm{H}), 7.42(\mathrm{~d}, 4 \mathrm{H}, J=8.7 \mathrm{~Hz}), 7.66-7.60(\mathrm{~m}, 4 \mathrm{H}), 7.73(\mathrm{~d}, 2 \mathrm{H}, J=15.9 \mathrm{~Hz}), 8.61-$

$8.59(\mathrm{~m}, 4 \mathrm{H}), 8.95(\mathrm{~s}, 1 \mathrm{H}) .{ }^{13} \mathrm{C}$ NMR and JMOD (75 MHz, $\left.\mathrm{CDCl}_{3}\right): \delta 163.0(\mathrm{C}), 158.2(\mathrm{C})$, $149.2(\mathrm{C}), 136.9(\mathrm{CH}), 136.6(\mathrm{CH}), 129.3(\mathrm{CH}), 125.0(\mathrm{C}), 122.2(\mathrm{CH}), 122.1(\mathrm{CH}), 121.7$ $(\mathrm{CH}), 120.85(\mathrm{CH}), 120.77(\mathrm{CH}), 112.6(\mathrm{CH}), 57.2\left(\mathrm{CH}_{2}\right)$. HRMS (ESI/ASAP): $\mathrm{m} / z$ calculated for $\mathrm{C}_{44} \mathrm{H}_{39} \mathrm{~N}_{8}[\mathrm{M}+\mathrm{H}]^{+}$679.3292, found 679.3284 .

\section{Results and Discussion}

\subsection{Preparation of Styryldiazine Derivatives.}

Styryldiazine derivatives are generally obtained by aldol condensation of aldehydes with methyldiazines in basic media [2,5,6a,10,15]. In this way, the target compounds $2 \mathbf{a}-\mathbf{e}$ were prepared in moderate-to-good yield by this well-established protocol from 4-(di-2picolylamino)benzaldehyde (1) and the corresponding methyldiazine in refluxing THF using potassium tert-butoxide as the base (Scheme 1). The 4,6-distyrylpyrimidine derivative 3 was also obtained in moderate yield starting from 4,6-dimethylpyrimidine.

\section{$<$ Scheme 1. $>$}

The new compounds exhibited good solubility in a variety of solvents, especially in THF, acetonitrile and chlorinated solvents, which allowed unequivocal characterization by NMR spectroscopy. The ${ }^{3} J(\mathrm{H}, \mathrm{H})$ coupling constants of $\sim 16.0 \mathrm{~Hz}$ for the vinylic protons in the

${ }^{1} \mathrm{H}$ NMR spectra indicated the selective formation of trans-configured double bonds in all condensation reactions.

\subsection{UV-vis and Fluorescence Spectroscopy.}

The photophysical properties of compounds $\mathbf{2}$ and $\mathbf{3}$ were examined by UV-vis and fluorescence spectroscopy in acetonitrile at $25^{\circ} \mathrm{C}$ and the results are summarized in Table 1. As one would expect, all of the absorption spectra showed a similar pattern with a $\pi-\pi^{*}$ transition in the UV or visible region at $\lambda_{\max }=364-410 \mathrm{~nm}$ accompanied by one or two extra bands at higher energy (Figure 1, see also Supporting Information). Typical emission maxima 
were obtained in the green-yellow region on irradiating the solutions. Pyrazine derivative $\mathbf{2 c}$ exhibited the highest fluorescence quantum yield $\left(\Phi_{\mathrm{F}}=0.24\right)$. In a similar way to other styryldiazine compounds [10d], quinoxaline derivative 2d showed a red-shifted absorption and emission band when compared to pyrimidine (2a), pyrazine (2c) and pyridazine (2e) derivatives. As far as pyrimidine derivatives are concerned, the introduction of pyridin-2-yl substituents at positions 2 and 4 of the pyrimidine ring in $\mathbf{2 b}$ led to bathochromic shifts in the absorption and emission spectra. Comparable red shifts were observed on going from 4styrylpyrimidine 2a to 4,6-distyrylpyrimidine $\mathbf{3}$, as observed previously for related systems [2b].

Table 1. Optical Spectroscopy Data for Dipicolylamine Styryldiazine Derivatives.

\begin{tabular}{clccc}
\hline Compd $^{a}$ & \multicolumn{1}{c}{$\lambda_{\mathrm{abs}}, \mathrm{nm}\left(\varepsilon, \mathrm{mM}^{-1} \cdot \mathrm{cm}^{-1}\right)$} & $\lambda_{\mathrm{em}}, \mathrm{nm}$ & $\Phi_{\mathrm{F}}{ }^{b}$ & Stokes shift, $\mathrm{cm}^{-1}$ \\
\hline 2a & $254(32.2), 326(15.8), 377(24.2)$ & 502 & 0.04 & 6605 \\
2b & $273(37.4), 402(27.7)$ & 557 & 0.13 & 6922 \\
2c & $259(21.3), 326(12.6), 377(19.8)$ & 522 & 0.24 & 7584 \\
2d & $257(18.9), 299(17.0), 410(29.0)$ & 593 & 0.15 & 7527 \\
2e & $255(15.7), 364(20.3)$ & 496 & 0.03 & 7311 \\
3 & $253(27.3), 330(18.9), 396(26.9)$ & 551 & 0.10 & 7104 \\
\hline
\end{tabular}

$\bar{a}$ All spectra were recorded in acetonitrile solutions at room temperature at $c=5.3-12.8 \times$ $10^{-6}$ M. ${ }^{b}$ Fluorescence quantum yield $( \pm 10 \%)$ determined relative to quinine sulfate in $0.1 \mathrm{M} \mathrm{H}_{2} \mathrm{SO}_{4}\left(\Phi_{\mathrm{F}}=0.54\right)$ and 9,10-diphenylanthracene in cyclohexane $\left(\Phi_{\mathrm{F}}=0.90\right)$ as standards.

\section{$<$ Figure 1.>}

It is worth noting that the fluorescence spectra showed significant solvatochromism (Table 2). An increase in the solvent polarity led to bathochromic shifts of the emission maxima, although the solvatochromic range was lower than for dimethylamino analogs [10d]. As an example, the spectra registered for compound $\mathbf{2 b}$ are shown in Figure 2, where the maximum emission wavelength at $\lambda_{\mathrm{em}}=473 \mathrm{~nm}$ in the least polar solvent (cyclohexane) is 
red-shifted by about $95 \mathrm{~nm}\left(\Delta v_{\mathrm{em}}=3536 \mathrm{~cm}^{-1}\right)$ in DMSO $\left(\lambda_{\mathrm{em}}=568 \mathrm{~nm}\right)$. This finding supports a highly polarized excited singlet state generated by the intramolecular charge transfer from the donor dipicolylamino group to the acceptor diazine groups. The large Stokes shifts (Table 1) are also indicative of the high polarizability of these systems due to the presence of both donor and acceptor groups coupled by a $\pi$-conjugated spacer. Nevertheless, solvatochromism is almost negligible in the absorption spectra, suggesting the absence of a significant electronic interaction between groups in the ground state.

Table 2. Emission Solvatochromism of Arylvinyldiazine Derivatives in Various Aprotic Solvents.

\begin{tabular}{lcccccc}
\hline & Cyclohexane & THF & DCM & Acetonitrile & DMSO & \\
& $\mathrm{E}_{\mathrm{T}}(30)^{\mathrm{a}}=30.9$ & $\mathrm{E}_{\mathrm{T}}(30)^{\mathrm{a}}=37.4$ & $\Delta \mathrm{E}_{\mathrm{T}}(30)^{\mathrm{a}}=40.7$ & $\Delta \mathrm{E}_{\mathrm{T}}(30)^{\mathrm{a}}=45.6$ & $\Delta \mathrm{E}_{\mathrm{T}}(30)^{\mathrm{a}}=45.1$ & \\
Compd & $\lambda_{\text {em }}, \mathrm{nm}$ & $\lambda_{\mathrm{em}}, \mathrm{nm}$ & $\lambda_{\mathrm{em}}, \mathrm{nm}$ & $\lambda_{\text {em }}, \mathrm{nm}$ & $\lambda_{\text {em }}, \mathrm{nm}$ & $\Delta v_{\mathrm{em}}{ }^{b} \mathrm{~cm}^{-1}$ \\
\hline $\mathbf{2 a}$ & 435 & 474 & 494 & 502 & 511 & 3419 \\
$\mathbf{2 b}$ & 473 & 518 & 531 & 557 & 568 & 3536 \\
$\mathbf{2 c}$ & 446 & 484 & 506 & 522 & 531 & 3589 \\
$\mathbf{2 d}$ & 493 & 536 & 557 & 593 & 600 & 3617 \\
$\mathbf{2 e}$ & 432,457 & 459 & 477 & 496 & 500 & $3148^{c}$ \\
$\mathbf{3}$ & 440,459 & 512 & 527 & 551 & 552 & $4611^{c}$ \\
\hline
\end{tabular}

${ }^{a}$ Dimroth-Reichardt polarity parameter, ${ }^{16} \mathrm{kcal} \cdot \mathrm{mol}^{-1} .{ }^{b} \Delta \mathrm{v}_{\mathrm{em}}=\mathrm{v}$ (cyclohexane) $-\mathrm{v}$ (DMSO).

${ }^{c}$ Using the more energetic emission band in cyclohexane.

$<$ Figure 2. $>$

Acetonitrile solutions of compounds $\mathbf{2 d}$ and $\mathbf{3}$ underwent significant color changes upon addition of TFA (Figure 3). Initially DPA is the most basic moiety in both molecules, but the electron-donating character of the DPA styryl chain increases the basicity of the quinoxaline and pyrimidine heterocyclic rings and makes it difficult to envisage the structure of the protonated species. We previously observed this phenomenon in related diazines and demonstrated the potential of these compounds as colorimetric $\mathrm{pH}$ sensors [2a,2e,6a,10c-e]. 
On the other hand, the emission was totally quenched after treatment with acid, as is generally observed for amino electron donor substituted diazines [2a,10d].

\section{<Figure 3.>}

The emission properties of compounds $\mathbf{2 a}-\mathbf{d}$ were also investigated in the presence of an excess of the metal cations $\mathrm{Zn}^{2+}, \mathrm{Cd}^{2+}$ and $\mathrm{Hg}^{2+}$. The results are presented in Table 3 . Different types of behavior were observed depending on the nature of the diazine ring. The addition of $\mathrm{Zn}^{2+}, \mathrm{Cd}^{2+}$ or $\mathrm{Hg}^{2+}$ led to a red shift associated with significant quenching of the fluorescence intensity in the case of pyrimidine derivatives $\mathbf{2 a}-\mathbf{b}$, whereas a blue shift was observed for pyrazine and quinoxaline derivatives $2 \mathbf{c}$ and $\mathbf{2 d}$. The emission spectra and fluorescence color changes observed for pyrazine derivative 2c are shown in Figures 4 and 5, respectively. It can be observed that only a moderate decrease in the fluorescence quantum yield was detected: $\Phi_{\mathrm{F}}(\mathbf{2 c})=0.24, \Phi_{\mathrm{F}}\left(\mathbf{2 c}+\mathrm{Zn}^{2+}\right)=0.04$ and $\Phi_{\mathrm{F}}\left(\mathbf{2 c}+\mathrm{Cd}^{2+}\right)=0.12$.

The emission characteristics are due to the different intramolecular charge transfer (ICT) properties of these push-pull molecules in response to coordination of the respective metal cations. Both the diazine and DPA groups can act as the metal binding site. Initially, the blue shift in $\mathbf{2 c - d}$ indicates a decreased CT into the molecules due to coordination of the metal cation on the DPA electron-donating group. Analogously, the red shift in $\mathbf{2 a}-\mathbf{b}$ could be explained by extra binding of the metal cation on the electron-attracting part of the pyrimidine, as reported for a related compound [8a]. Indeed, pyrimidine is a stronger base than pyrazine and quinoxaline. These results show that metal cations can be used as external stimuli for the modulation of emission colors in these systems. Nevertheless, further quantitative investigations are required to determine the optimum stoichiometry and coordination properties. This work is currently in progress in our laboratories.

Table 3. Emission Maxima ${ }^{a}$ of 2 a-d after Treatment with Excess Metal Cations. ${ }^{b}$

$$
\text { No cation }+\mathrm{Zn}^{2+}+\mathrm{Cd}^{2+}+\mathrm{Hg}^{2+}
$$




\begin{tabular}{ccccc}
$\operatorname{Compd}^{a}$ & $\lambda_{\text {em }}, \mathrm{nm}$ & $\lambda_{\mathrm{em}}, \mathrm{nm}$ & $\lambda_{\mathrm{em}}, \mathrm{nm}$ & $\lambda_{\mathrm{em}}, \mathrm{nm}$ \\
\hline 2a & 502 & 516 & 507 & 526 \\
2b & 557 & 592 & 580 & 606 \\
2c & 522 & 447 & 481 & 517 \\
2d & 593 & 523 & 554 & 595 \\
\hline${ }^{a}$ Acetonitrile solutions. & ${ }^{b}$ Chloride salts.
\end{tabular}

<Figure 4.>

$<$ Figure 5. $>$

\subsection{Calculations.}

The HOMO and LUMO levels, their differences as well as the ground state dipole moments of target compounds $\mathbf{2 a - e}$ and $\mathbf{3}$ were studied by semi-empirical calculations. Initial geometries were calculated by PM3 implemented in ArgusLab [17] and subsequently optimized by PM7 in MOPAC [18]. The calculated values are summarized in Table 4. Figure 6 shows the optimized geometries and the HOMO and LUMO localizations for each particular derivative [19].

Table 4. PM7 calculated parameters of molecules 2a-e and 3

\begin{tabular}{cccccc}
\hline Compd & $\begin{array}{c}E_{\mathrm{HOMO}} \\
{[\mathrm{eV}]}\end{array}$ & $\begin{array}{c}E_{\mathrm{LUMO}} \\
{[\mathrm{eV}]}\end{array}$ & $\begin{array}{c}\Delta E \\
{[\mathrm{eV}]}\end{array}$ & $\begin{array}{c}\mu \\
{[\mathrm{D}]}\end{array}$ & $\begin{array}{c}\lambda_{\mathrm{abs}} \\
{[\mathrm{eV}]^{a}}\end{array}$ \\
\hline $\mathbf{2 a}$ & -8.25 & -0.98 & 7.27 & 6.82 & 3.29 \\
$\mathbf{2 b}$ & -8.16 & -0.98 & 7.18 & 2.59 & 3.08 \\
$\mathbf{2 c}$ & -8.22 & -1.00 & 7.22 & 4.66 & 3.29 \\
$\mathbf{2 d}$ & -8.20 & -1.11 & 7.09 & 4.27 & 3.02 \\
$\mathbf{2 e}$ & -8.23 & -0.98 & 7.25 & 7.67 & 3.41 \\
$\mathbf{3}$ & -8.17 & -0.79 & 7.38 & 6.34 & 3.13 \\
\hline${ }^{a}$ Experimental longest-wavelength absorption maxima \\
measured in acetonitrile (1240/ $\left.\lambda_{\mathrm{abs}}\right)$.
\end{tabular}

The calculated energies of the HOMO and LUMO range from -8.25 to -8.16 and -1.11 to $0.79 \mathrm{eV}$, respectively. Although these values are generally overestimated and should be treated with precaution, the calculated HOMO-LUMO gaps $(\Delta E)$ for $\mathbf{2 a - e}$ correlates well with the position of the experimentally obtained longest-wavelength absorption maxima $\left(R^{2}=0.8\right)$. Hence, the PM7 calculations are capable to describe the trends within this series of molecules. 
Although the changes in $\Delta E$ are relatively small, some structure-property relationships can be elucidated. When going from $\mathbf{2 a}$ to $\mathbf{2 b}$, the gap has decreased by $0.09 \mathrm{eV}$ as a result of attaching two pyridine-2-yl rings to the pyrimidine acceptor. The replacement by a pyrazine ring (2a to 2c) lowered the gap negligibly by $0.05 \mathrm{eV}$. However, its further extension by a fused benzene ring as in $\mathbf{2 d}$ resulted in the lowest gap of $7.09 \mathrm{eV}$. Pyridazin-3-yl acceptor in 2e delivered very similar HOMO-LUMO gap $(\Delta E=7.25 \mathrm{eV})$ as pyrimidin-4-yl $(\mathbf{2 a} ; \Delta E=$ $7.27 \mathrm{eV})$ and pyrazine-3-yl (2c; $\Delta E=7.22 \mathrm{eV})$.

\section{$<$ Figure 6. $>$}

The HOMO and LUMO visualizations shown in Figure 6 clearly show charge separation and thus further confirms ICT character of molecules 2a-e and 3. As expected, the HOMO is predominantly localized on the amino donor and the adjacent $\pi$-system, whereas the LUMO is spread over the diazine acceptors.

\section{Conclusions}

A series of push-pull dipicolylamine styryldiazine derivatives has been efficiently synthesized by aldol condensation between 4-(di-2-picolylamino)benzaldehyde and the appropriate methyldiazine. The new compounds were fully characterized. All of the molecules presented absorption wavelengths in the UV or visible region and emit light with significant Stokes shifts. The presence of both a donor and an acceptor group coupled by a $\pi$-conjugated spacer enables intramolecular charge transfer processes that lead to highly polarized singlet excited states. This situation is reflected by large red shifts in the fluorescence emission maxima upon increasing the solvent polarity and supported by semi-empirical calculations. As in other related diazines, $\mathbf{2 d}$ and $\mathbf{3}$ undergo significant color change upon addition of acid and this property highlights their potential as colorimetric $\mathrm{pH}$ sensors. Moreover, the addition of 
different metal cations resulted in blue or red shifts in the fluorescence spectra and this effect may become a powerful tool for the development of multicolor emitters.

\section{Acknowledgment}

We thank Jérôme Orain and Kevin Babe for some preliminary syntheses. J.R.-L. thanks the Junta de Comunidades de Castilla-La Mancha/FEDER (EU) - project PEII-2014-005-A - for financial support.

\section{Appendix A. Supplementary data}

Supplementary data related to this article can be found at http://dx.doi.org/... 
Scheme 1. Synthesis of Dipicolylamine Styryldiazine Derivatives 2 and 3

Figure 1. Normalized UV/vis (solid lines) and emission (dashed lines) spectra of compounds 2c (red) and 2d (blue). See Supporting Information for spectra of all compounds.

Figure 2. Normalized emission of compound $\mathbf{2 b}$ in different aprotic solvents.

Figure 3. Color change of acetonitrile solutions of $\mathbf{2} \mathbf{d}$ and $\mathbf{3}$ after treatment with TFA.

Figure 4. Normalized emission spectra of $\mathbf{2 c}$ in acetonitrile with excess metal cations (as chloride salts).

Figure 5. Fluorescence colors of an acetonitrile solution of $2 \mathbf{c}$ in the presence of excess metal cations. Photographs were taken in the dark upon irradiation with a hand-held UV lamp $\left(\lambda_{\mathrm{em}}=\right.$ $366 \mathrm{~nm})$.

Figure 6. Optimized geometries and HOMO (red) and LUMO (blue) localizations in 2a-e and 3. 


\section{References}

[1] (a) Achelle S, Baudequin C. Recent advances in pyrimidine derivatives as luminescent, photovoltaic and ono-linear optical materials. Targets Heterocycl Syst 2013;17:1-34. (b) Achelle S, Baudequin C, Plé N. Luminescent materials incorporating pyridazine or quinoxaline moieties. Dyes Pigm 2013;98:575-600. (c) Achelle S, Plé N. Pyrimidine ring as building block for the synthesis of functionalized П-conjugated materials. Curr Org Synth 2012;9:163-87. (d) Achelle S, Plé N, Turck A. Incorporation of pyridazine rings in the structure of functionalized П-conjugated materials. RSC Adv 2011;1:364-88.

[2] (a) Achelle S, Rodríguez-López J, Robin-le Guen F. Synthesis and photophysical studies of a series of quinazoline chromophores. J Org Chem 2014;79:7564-71. (b) Denneval C, Achelle S, Baudequin C, Robin-le Guen F. Prediction of photophysical properties of pyrimidine chromophores using Taguchi method. Dyes Pigm 2014:110:49-55. (c) Schmitt V, Moschel S, Detert H. Diarylstyrylpyrazines: solvatochromic and acidochromic fluorophores. Eur J Org Chem 2013;5655-69. (d) Lincker F, Kreher D, Attias A-J, Do J, Kim E, Hapiot P, Lemaître N, Geffroy B, Ulrich G, Ziessel R. Rodlike fluorescent $\pi$-conjugated 3,3'bipyridazine ligand: optical electronic and complexation properties. Inorg Chem 2010;49:3991-4001. (e) Achelle S, Nouira I, Pfaffinger B, Ramondenc Y, Plé N, RodríguezLópez J. V-shaped 4,6-Bis(arylvinyl)pyrimidine oligomers : synthesis and optical properties. J Org Chem 2009;74:3711-7.

[3] (a) Wink C, Detert H. Donor-substituted distyrylpyrazines: influence of steric congestion on UV-Vis absorption and fluorescence. J Phys Org Chem 2013;26:137-43. (b) Jaung JY. Synthesis and halochromism of new quinoxaline fluorescent dyes. Dyes Pigm 2006;71:24550. 
[4] (a) Das S, Sahana A, Banerjee A, Lohar S, Safin DA, Babashkina MG, Bolte M, Garcia Y, Hauli I, Mukhopadhyay SK, Das D. Ratiometric fluorescence sensing and intracellular imaging of $\mathrm{Al}^{3+}$ ions driven by an intramolecular excimer formation of a pyrimidine-pyrene scaffold. Dalton Trans 2013;42:4757-63. (b) Weng J, Mei Q, Ling Q, Fan Q, Huang W. A new colorimetric and fluorescent ratiometric sensor for $\mathrm{Hg}^{2+}$ based on 4-pyren-1-ylpyrimidine. Tetrahedron 2012;68:3129-34. (c) Wu FY, Bae SW, Hong JI. A selective fluorescent sensor for $\mathrm{Pb}(\mathrm{II})$ in water. Tetrahedron Lett 2006;47:8851-4.

[5] Boländer A, Kieser D, Voss C, Bauer S, Schön C, Burgold S, Bittner T, Hölzer J, Heynyvon Haussen R, Mall G, Goetschy V, Czech C, Knust H, Berger R, Herms J, Hilger I, Schmidt B. Bis(arylvinyl)pyrazines, -pyrimidines, and -pyridazines as imaging agents for tau fibrils and $\beta$-amyloid plaques in Alzeimer's disease models. J Med Chem 2012;55:9170-80.

[6] (a) Aranda AI, Achelle S, Hammerer F, Mahuteau-Betzer F, Teulade-Fichou M-P. Vinyldiazine triphenylamines and their N-methylated derivatives: synthesis, photophysical properties and application for staining DNA. Dyes Pigm 2012;95:400-7. (b) Miura S, Nishizawa S, Suzuki A, Fujimoto Y, Ono K, Gao Q, Teramae N. DNA-binding small-ligandimmobilized surface plasmon resonance biosensor for detecting thymine-related singlenucleotide polymorphisms. Chem-Eur J 2011;17:14104-10.

[7] Liu D, Zhang Z, Zhang H, Wang Y. A novel approach towards white photoluminescence and electroluminescence by controlled protonation of a blue fluorophore. Chem Commun 2013;49:10001-3.

[ 8 ] (a) Shiraishi Y, Ichimura C, Sumiya S, Hirai T. Multicolor fluorescence of a styrylquinoline dye tuned by metal cations. Chem-Eur J 2011;17:8324-32. (b) Xu Z, Han SJ, Lee C, Yoon J, Spring DR. Development of off-on fluorescent probes for heavy and transition metal ions. Chem Commun 2010;46:1679-81. (c) Fluorescent Chemosensors for Ion and 
Molecular Recognition (Ed.: A. Czarnik), American Chemical Society, Washington DC, 1993.

[9] (a) Zheng M, Sun M, Zhang D, Liu T, Xue S, Yang W. Fluorescence response of pyridinyl- and/or dibutylaniline-capped 2,6,9,10-tetravinylanthracenes to metal ions. Dyes Pigm 2014;101:109-15. (b) Ast S, Fischer T, Müller H, Mickler W, Schwichtenberg M, Rurack K, Holdt HJ. Integration of the 1,2,3-triazole "click" motif as a potent signaling element in metal ion responsive fluorescent probes. Chem-Eur J 2013;19:2990-3005. (c) Hauck M, Schönhaber J, Zucchero AJ, Hardcastle KI, Müller TJJ, Bunz UHF. Phenothiazine cruciforms: synthesis and metallochromic properties. J Org Chem 2007;72:6714-25. (d) Spitler EL, Shirtcliff LD, Haley MM. Systematic structure-property investigations and ionsensing studies of pyridine-derivatized donor/acceptor tetrakis(arylethynyl)benzenes. J Org Chem 2007;72:86-96. (e) Li YQ, Bricks JL, Resch-Genger U, Spieles M, Rettig W. Bifunctional charge transfer operated fluorescent probes with acceptor and donor receptors. 2. Bifunctional catión coordination behavior of biphenyl-type sensor molecules incorporating 2,2':6',2'’-terpyridine acceptors. J Phys Chem A 2006;110:10972-84. (f) Wilson JN, Bunz UHF. Switching of intramolecular charge transfer in cruciforms: metal ion sensing. $\mathrm{J}$ Am Chem Soc 2005;127:4124-5.

[10] (a) Malval JP, Achelle S, Bodiou L, Spangenberg A, Gomez LC, Soppera O, Robin-le Guen F. Two-photon absorption in az conformationally twisted D- $\pi$-A oligomer: a synergic photosensitizing approach for multiphoton lithography. J Mater Chem C 2014;2:7869-80. (b) Achelle S, Kahlal, S, Saillard JY, Cabon N, Caro B, Robin-le Guen F. Dipolar and V-shaped structures incorporating methylenepyran and diazine fragments. Tetrahedron 2014;70:280415. (c) Achelle S, Robin-le Guen F. 2-arylvinylpyrimidines versus 4-arylvinylpyrimidines: synthesis and comparison of the optical properties. Tetrahedron Lett 2013;54:4491-6. (d) 
Achelle S, Barsella A, Baudequin C, Caro B, Robin-le Guen F. Synthesis and photophysical investigation of a series of push-pull arylvinyldiazine chromophores. J Org Chem 2012;77:4087-96. (e) Hadad C, Achelle S, García-Martínez JC, Rodríguez-López J. 4arylvinyl-2,6-di(pyridin-2-yl)pyrimidines: synthesis and optical properties. J Org Chem 2011;76:3837-45.

[11] (a) Hufura A, Taniyama H, Son SH, Yamada K, Takahashi M, Okabe S, Satoh H. BODIPY-based ratiometric fluoroionophores with bidirectional spectral shifts for the selective recognition of heavy metal ions. Bull Chem Soc Jpn 2013;86:37-44. (b) Yang XB, Yang BX, Ge JF, Xu YJ, Xu QF, Liang J, Lu JM. Benzo[a]phenoxazinium-based red-emitting chemosensor for zinc ions in biological media. Org Lett 2011;13:2710-3. (c) Liu Z, Zhang C, He W, Yang Z, Gao X, Guo Z. A highly sensitive ratiometric fluorescent probe for $\mathrm{Cd}^{2+}$ detection in aqueous solution and living cells. Chem Commun 2010;46:6138-40. (d) Bozmedir OA, Guliyev R, Buyukcakir O, Selcuk S, Kolemen S, Guiseren G, Nalbantoglu T, Boyaci H, Akkaya EU. Selective manipulation of ICT and PET processes in styryl-bodipy derivatives: applications in molecular logic and fluorescence sensing of metal ions. $\mathrm{J}$ Am Chem Soc 2010;132:8029-36. (e) Lee HG, Lee JH, Jang SP, Park HM, Kim SJ, Kim Y, Kim C, Harrison RG. Zinc selective chemosensor based on pyridyl-amide fluorescence Tetrahedron 2011;67:8073-8. (f) Lee HG, Lee JH, Jang SP, Hwang IH, Kim SJ, Kim Y, Kim C, Harrison RG. Zinc selective chemosensors base don the flexible dipicolylamine and quinoline. Inorg Chim Acta 2013;394:542-51.

[12] Hadad C, Achelle S, López-Solera I, García-Martínez JC, Rodríguez-López J. Metal cation complexation studies of 4-arylvinyl-2,6-di(pyridin-2-yl)pyrimidines: effect on the optical properties. Dyes Pigm 2013;97:230-7. 
[13] Peng X, Du J, Fan J, Wang J, Wu Y, Zhao J, Sun S, Xu T. A selective fluorescent sensor for imaging $\mathrm{Cd}^{2+}$ in living cells. J Am Chem Soc 2007;129:1500-1.

[14] Eaton DF. Reference materials for fluorescence measurement Pure Appl Chem 1988;60:1107-14.

[15] (a) Lipunova GN, Nosova EV, Trashakhova TV, Charushin VN. Azinylarylethenes: synthesis and photophysical and photochemical properties. Russ Chem Rev 2011;80:111533. (b) Vanden Eynde JJ, Pascal L, Van Haverbeke Y, Dubois P. Quaternary amonium saltassisted synthesis of extended pi-systems from methyldiazines and aromatic aldehydes. Synth Commun 2001;31:3167-73.

[16] Reichardt C. Solvatochromic dyes as solvent polarity indicators. Chem Rev 1994;94: 2319-58.

[ 17 ] ArgusLab 4.0, Thompson MA. Planaria Software LLC, Seattle, WA. http://www.arguslab.com

[18] MOPAC2012, Stewart JJP. Stewart Computational Chemistry, Version 15.089W. http://OpenMOPAC.net

[19] Pytela O. OPchem, version 6.2, webpage: http://pytela.upce.cz/OPgm. 


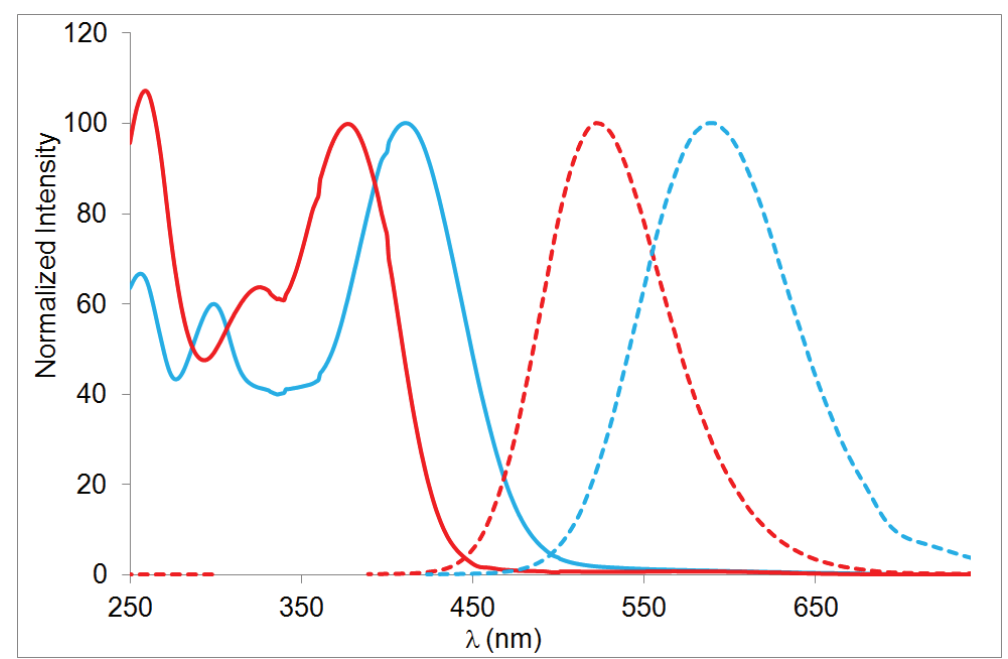



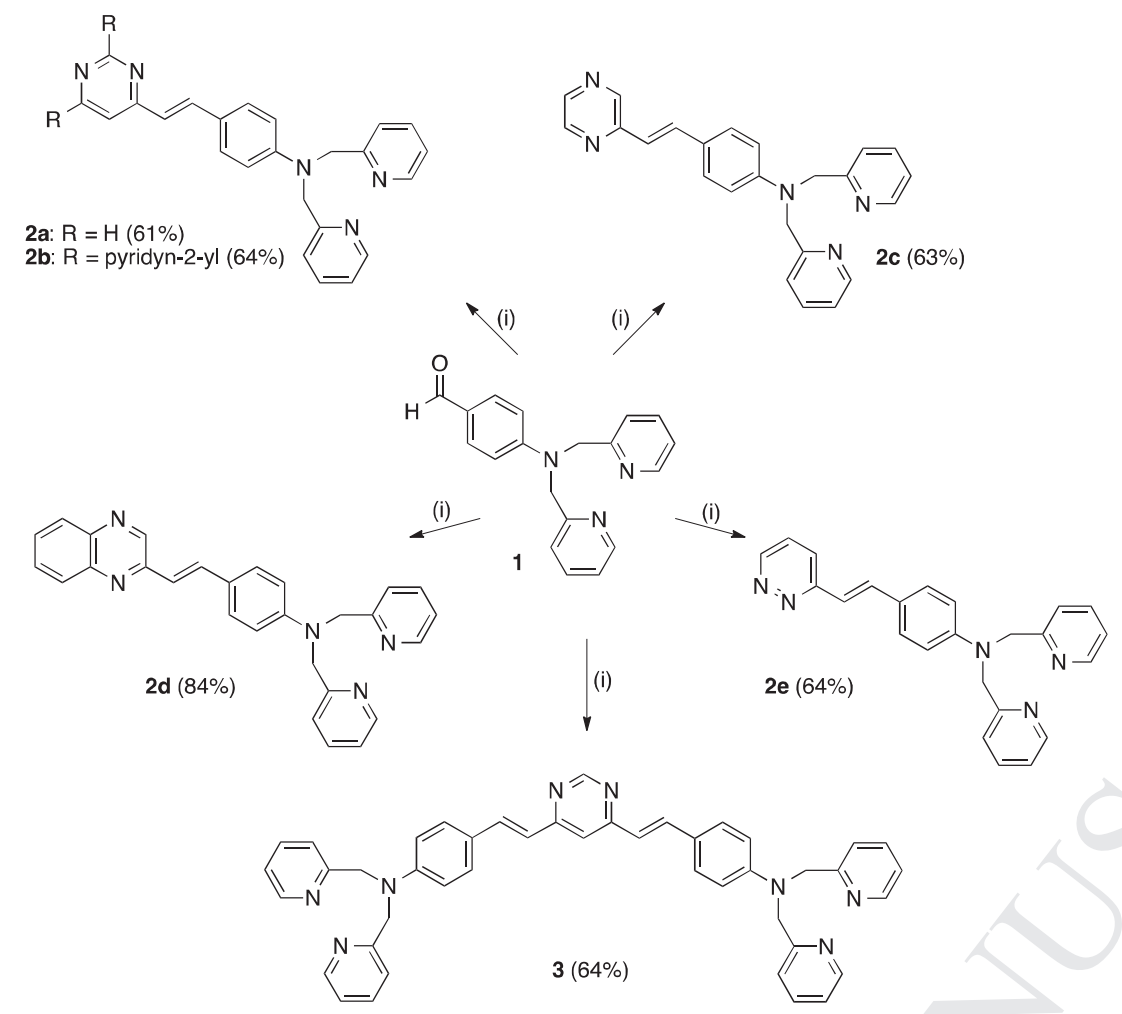

(i) 4-Methylpyrimidine for 2a, 4-methyl-2,6-di-pyridin-2-yl-pyrimidine for 2b, 2-methylpyrazine for 2c, 2-methylquinoxaline for $\mathbf{2 d}$, 3-methylpyridazine for $2 \mathrm{e}$ or 4,6 -dimethylpyrimidine for $3 / \mathrm{K}$ BuO, THF, $\Delta, 15 \mathrm{~h}$. 


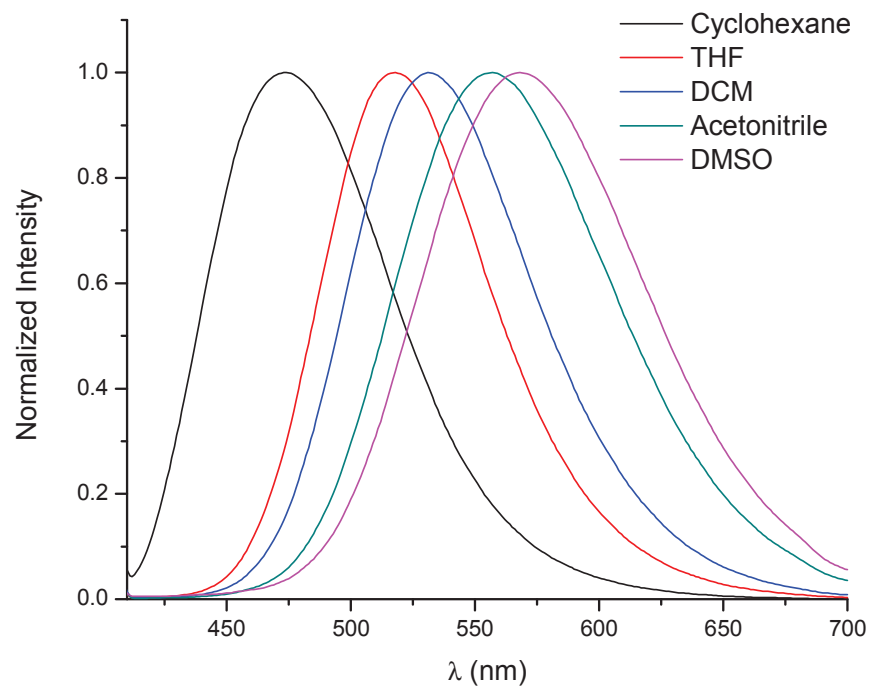




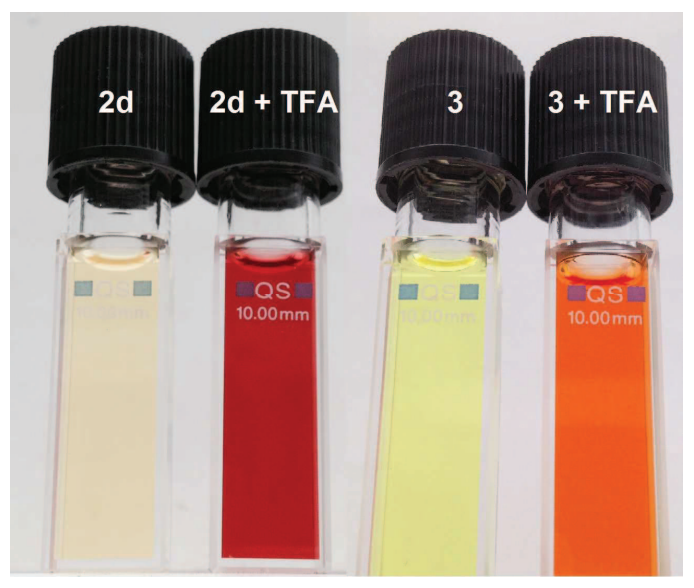




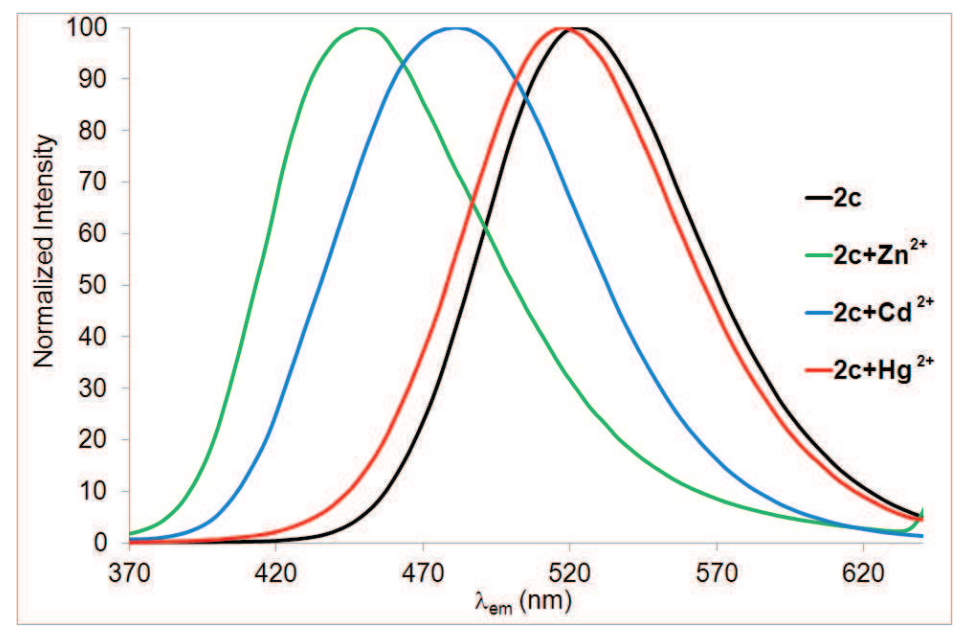




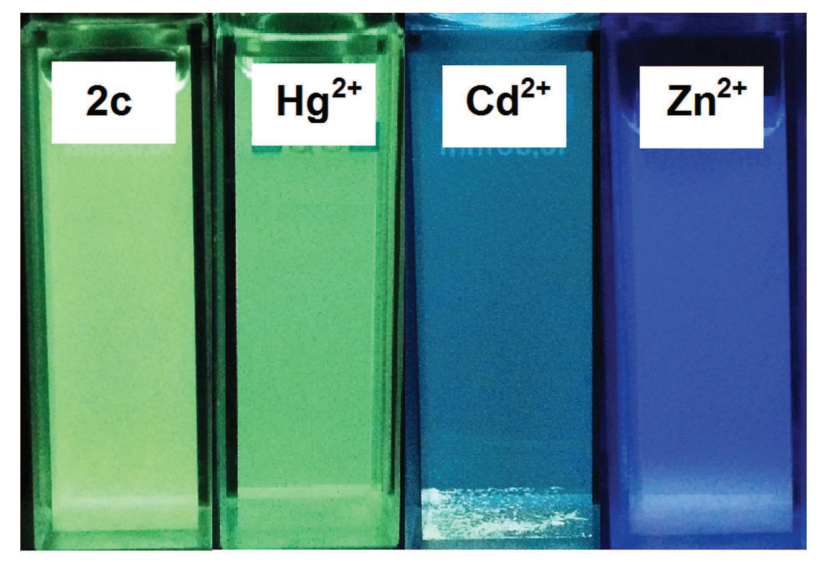



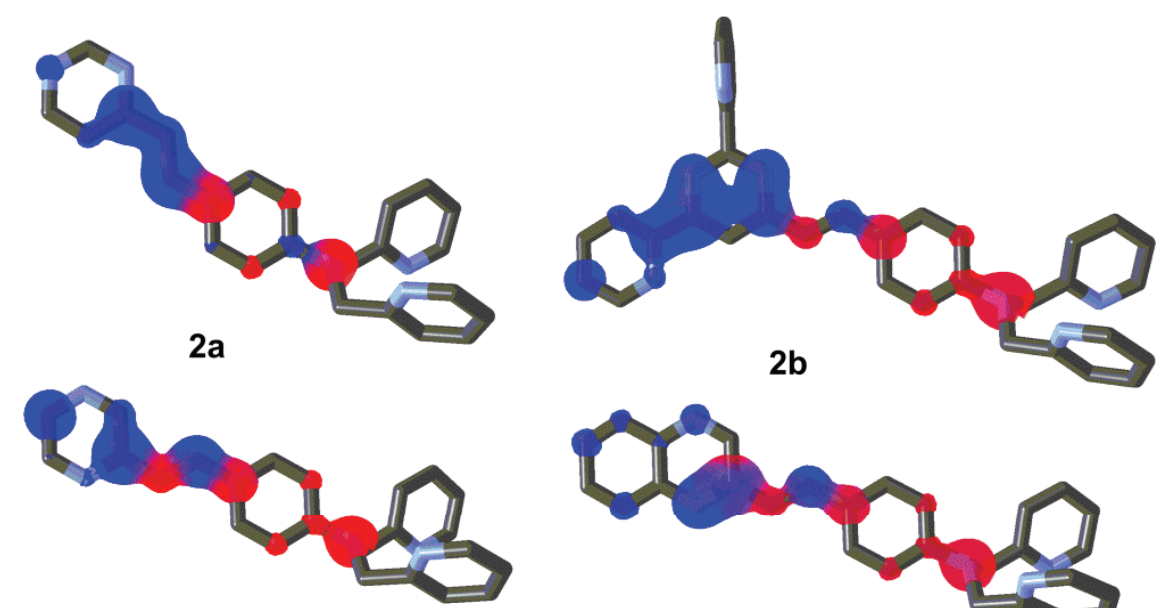

2c
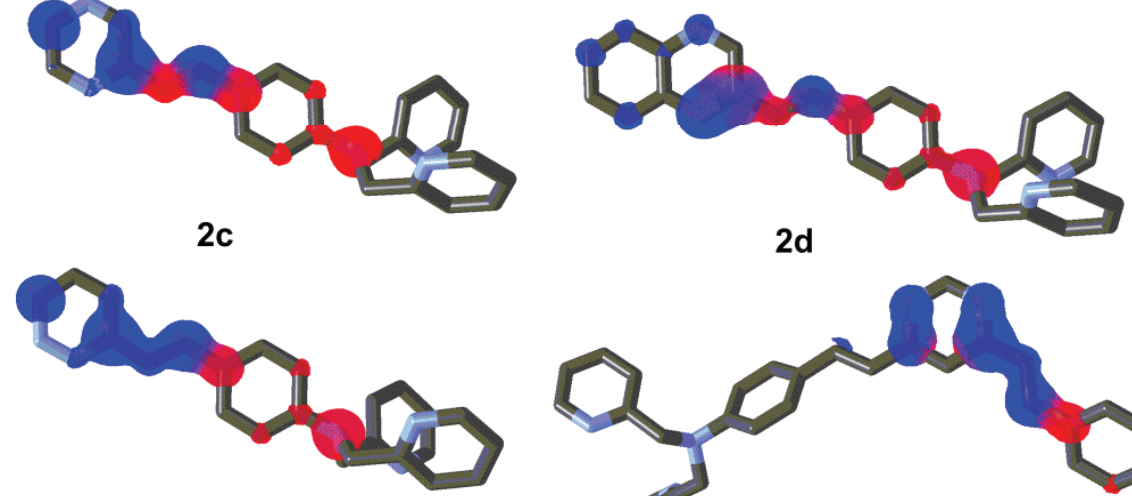

$2 \mathrm{e}$

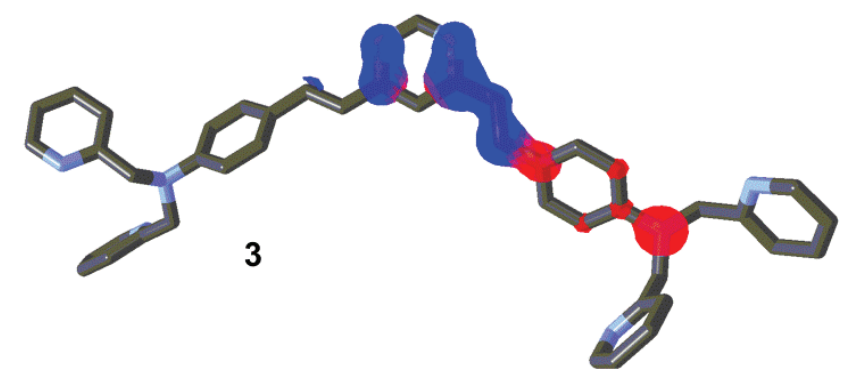


D- $\pi$-A molecules with dipicolylamine group and diazines rings were synthesized.

All the compounds showed yellow-green light emission.

All the compounds exhibit significant emission solvatochromism.

Coordination of metal cations leads to blue or red shift in the fluorescence spectra 


\section{Dipicolylamine Styryldiazine Derivatives: Synthesis and Photophysical Studies.}

Sylvain Achelle*,a, Julián Rodríguez-López*,b, Filip Burešc , and Françoise Robin-le Guen ${ }^{\mathrm{a}}$

${ }^{a}$ Institut des Sciences Chimiques de Rennes UMR CNRS 6226, IUT de Lannion, rue Edouard Branly, BP 30219, F22302 Lannion Cedex, France. ${ }^{\text {b}}$ Facultad de Ciencias y Tecnologías Químicas, Universidad de Castilla-La Mancha, 13071 Ciudad Real, Spain. ${ }^{\mathrm{c} I n s t i t u t e ~ o f ~}$ Organic Chemistry and Technology, Faculty of Chemical Technology, University of Pardubice, Studentská 573, Pardubice 53210, Czech Republic

Corresponding authors: *E-mail: sylvain.achelle@univ-rennes1.fr; julian.rodriguez@uclm.es

\section{Table of contents}

1. NMR spectra for compound 2a (p S2).

2. NMR spectra for compound $\mathbf{2} \mathbf{b}(\mathrm{p} \mathrm{S} 3)$.

3. NMR spectra for compound 2c (p S4).

4. NMR spectra for compound $\mathbf{2 d}$ (p S5).

5. NMR spectra for compound $2 \mathrm{e}(\mathrm{p} \mathrm{S} 6)$.

6. NMR spectra for compound 3 (p S7).

7. UV/Vis and emission spectra for compounds $\mathbf{2 a - e}$ and $\mathbf{3}$ in $\mathrm{MeCN}$ (p S8).

8. Emission spectra of compounds 2a-e and $\mathbf{3}$ in various solvents (p S9-S11)

9. Normalized absorption spectra of compound $\mathbf{2 d}$ and $\mathbf{3}$ in MeCN+TFA (p S11) 

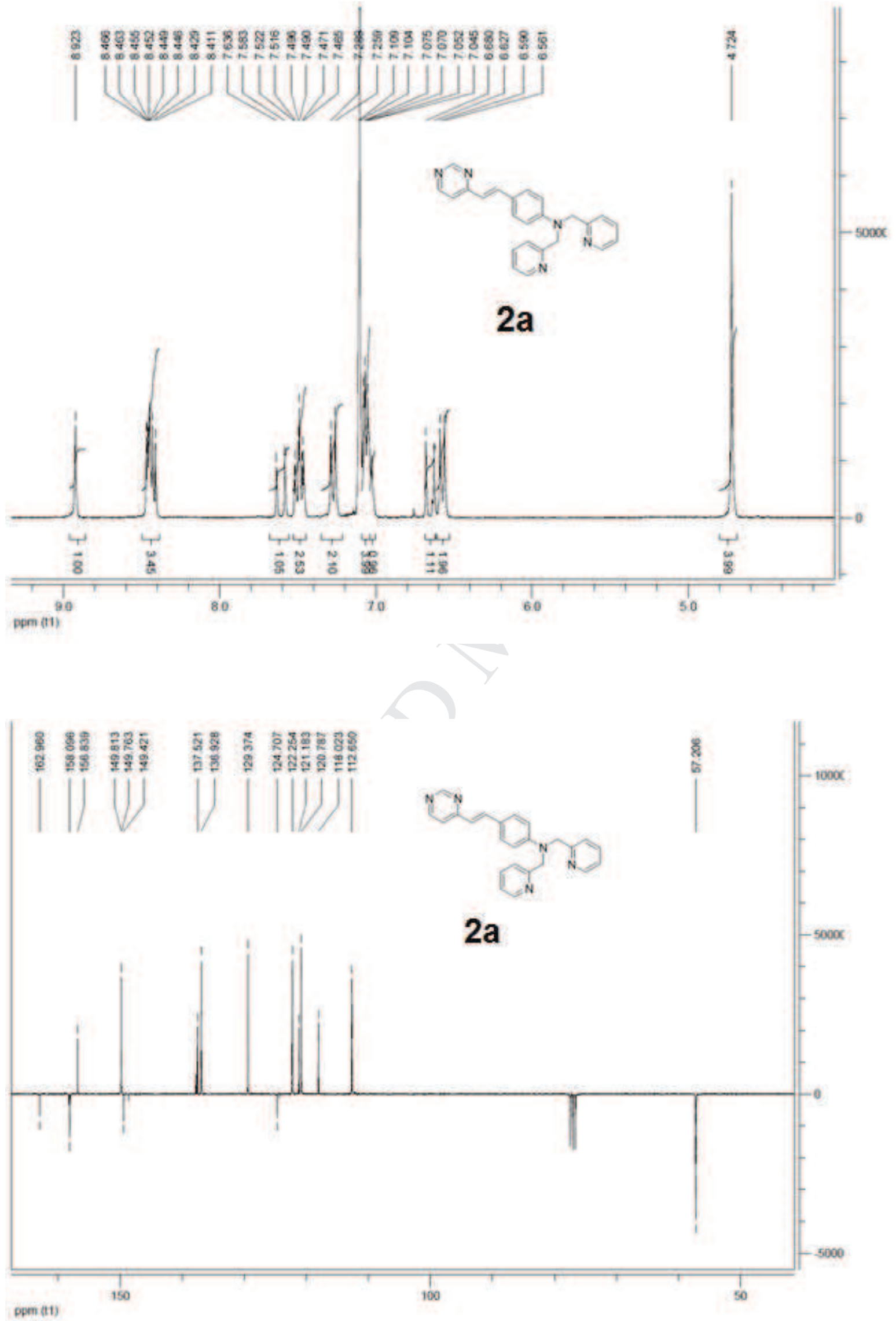

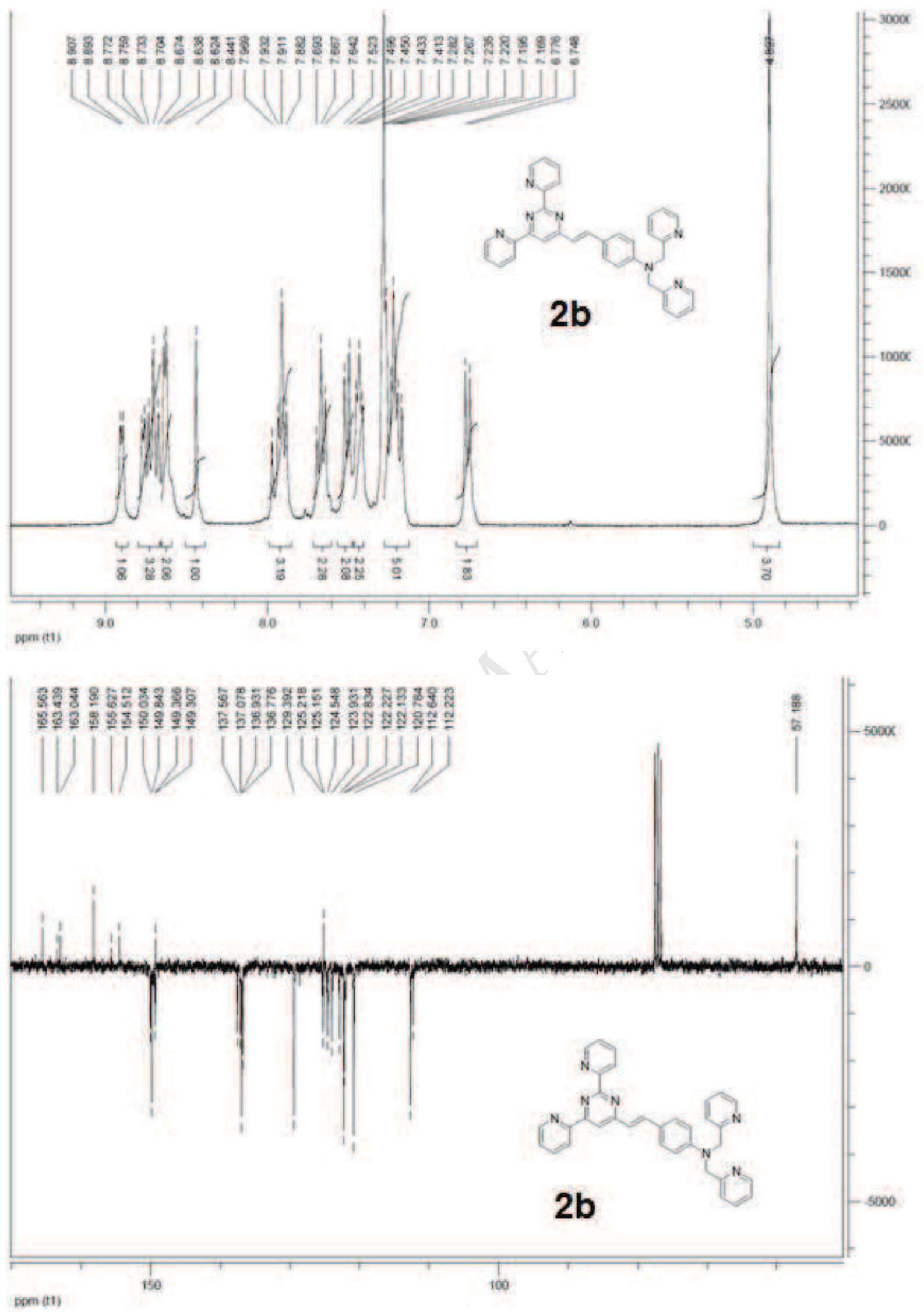

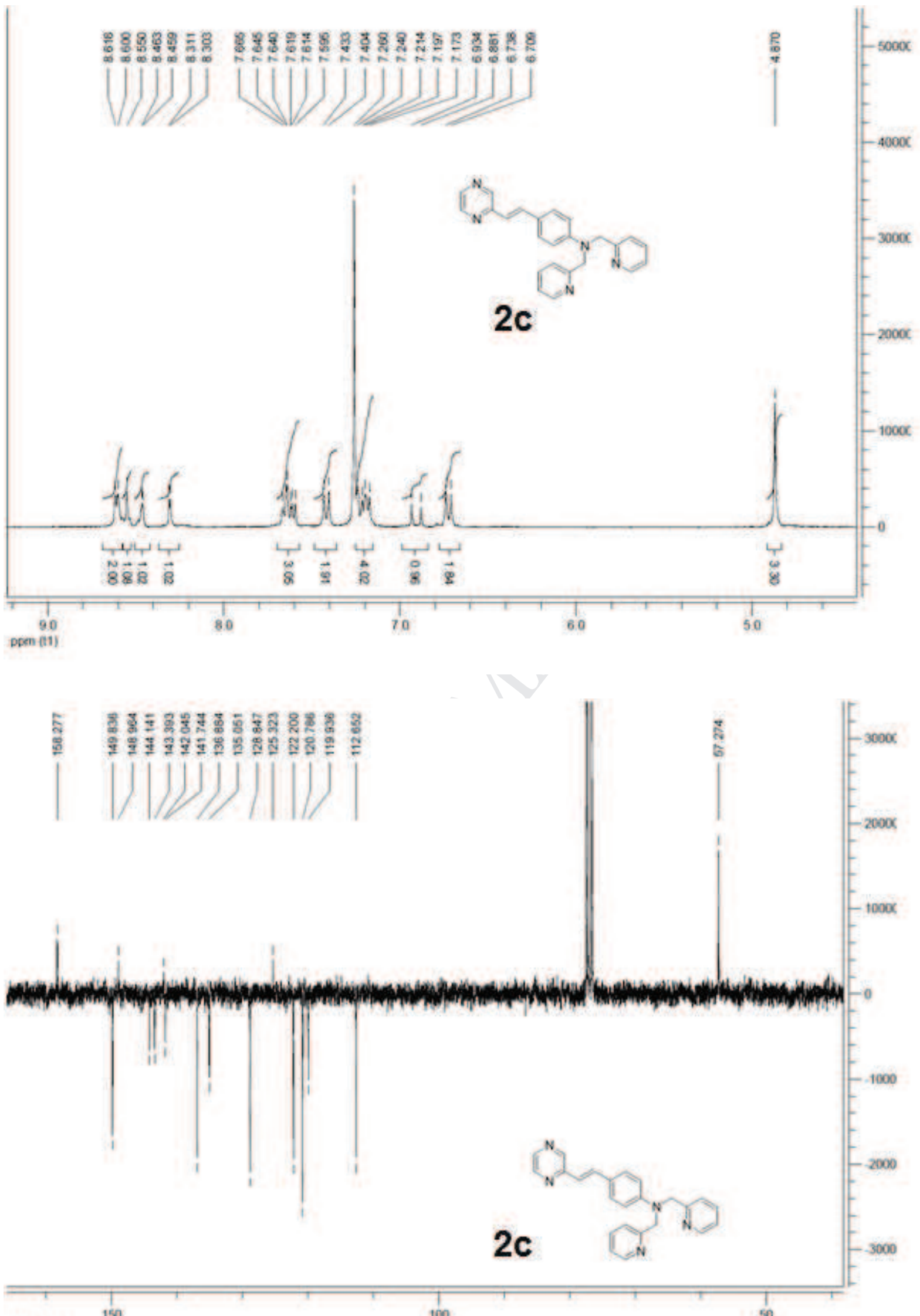

ppon (11) 


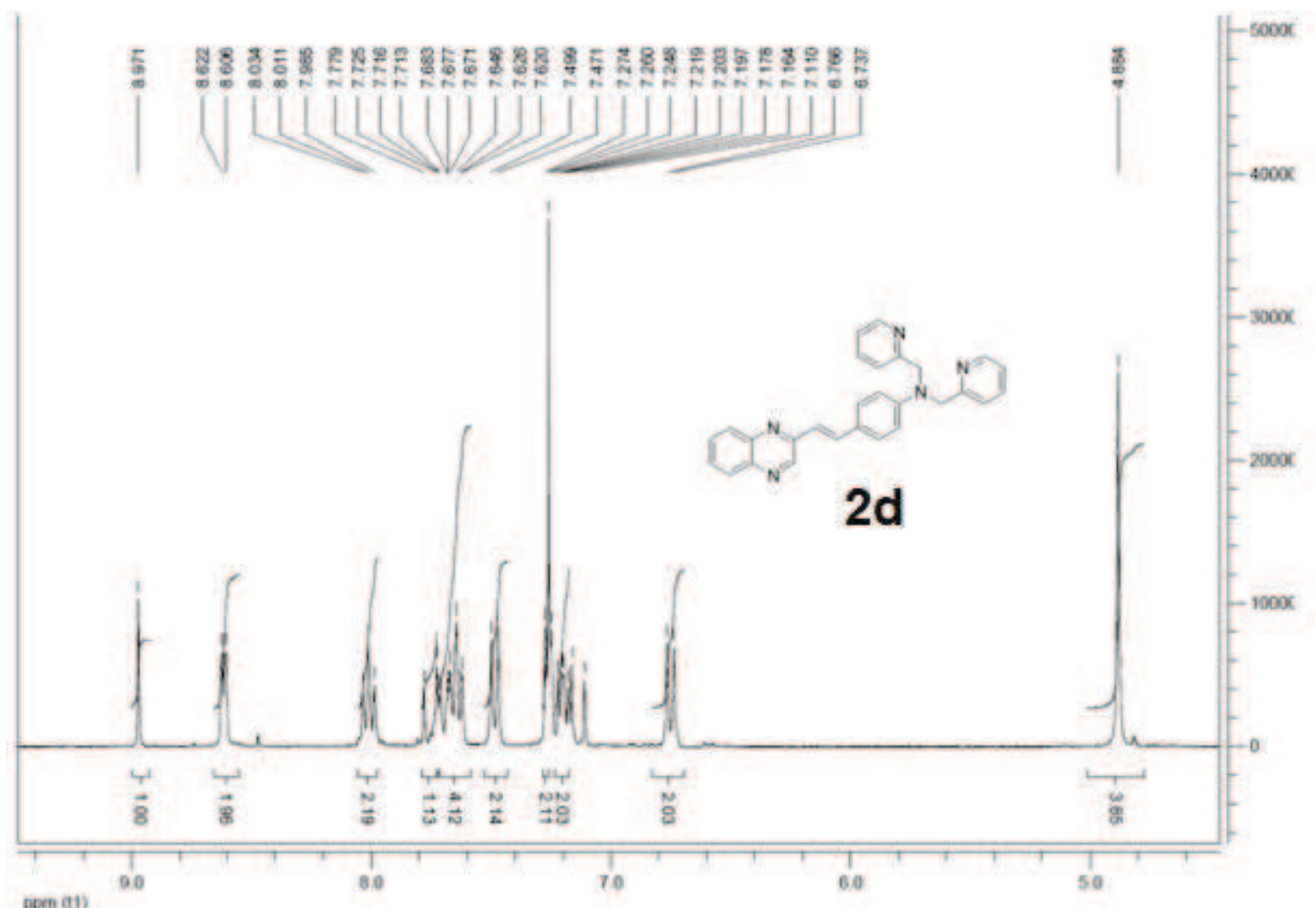

spen a1)

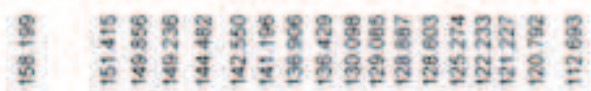

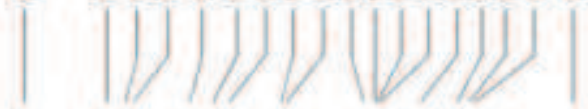

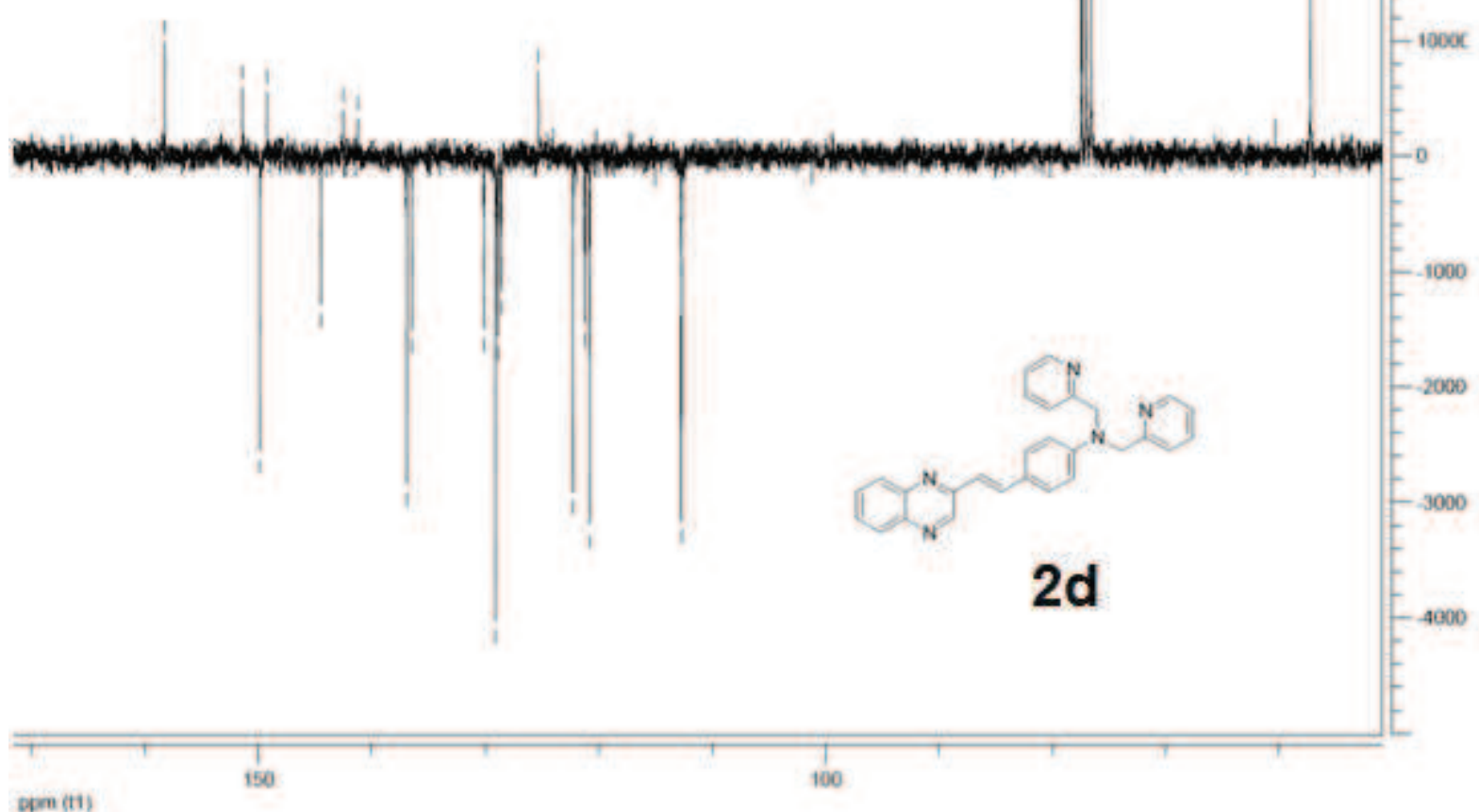

(4) (t1) 


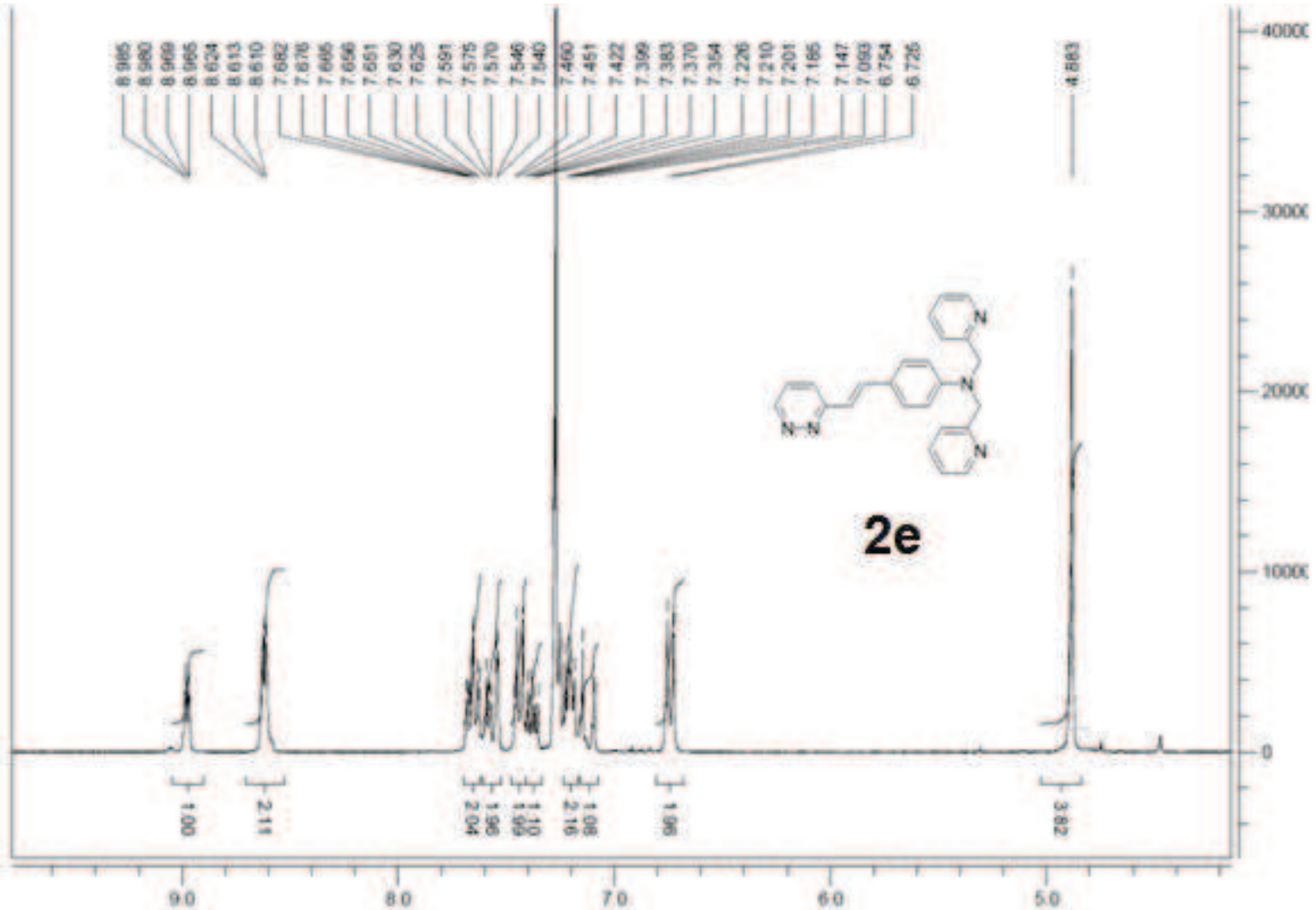

pom (11)

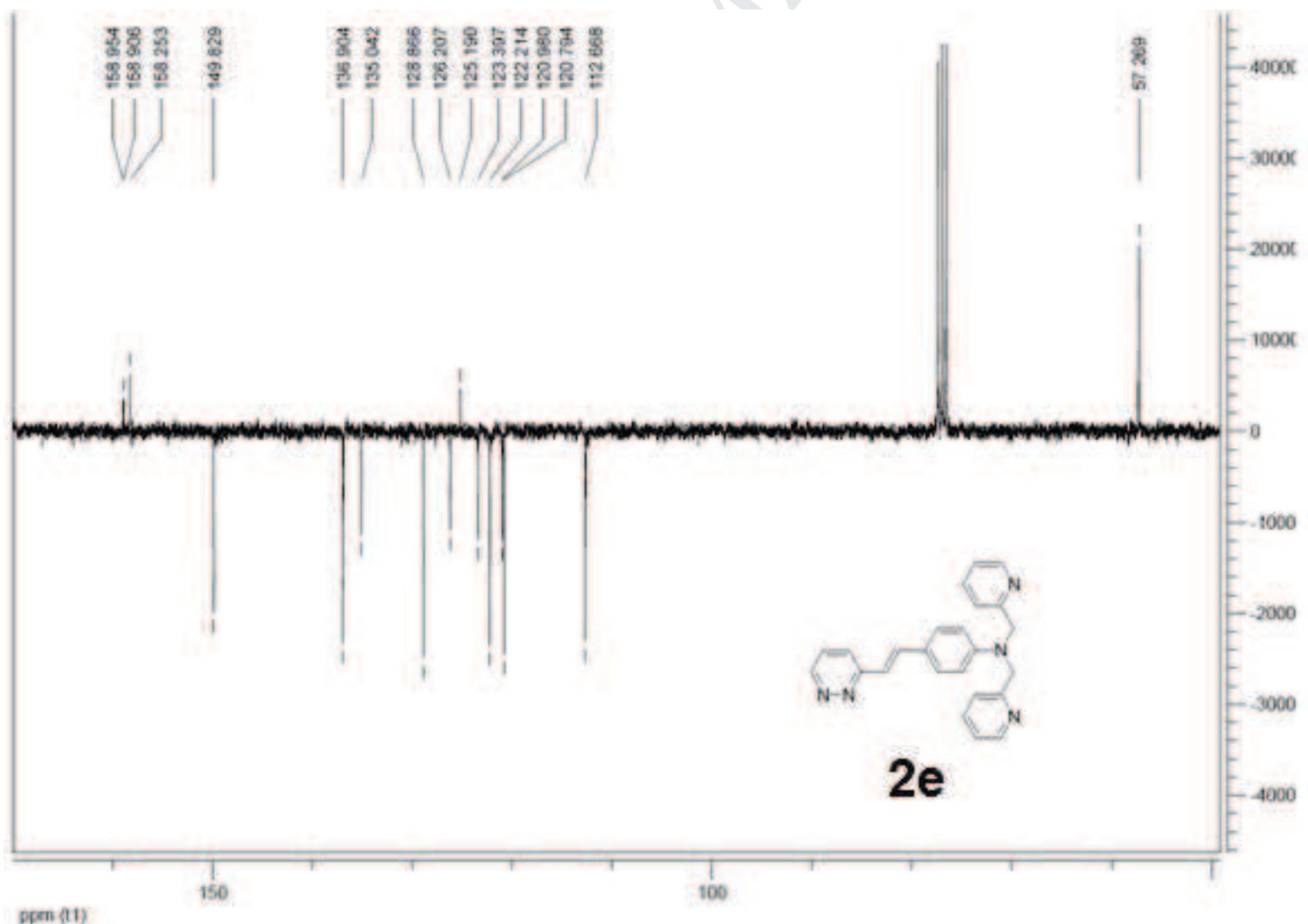




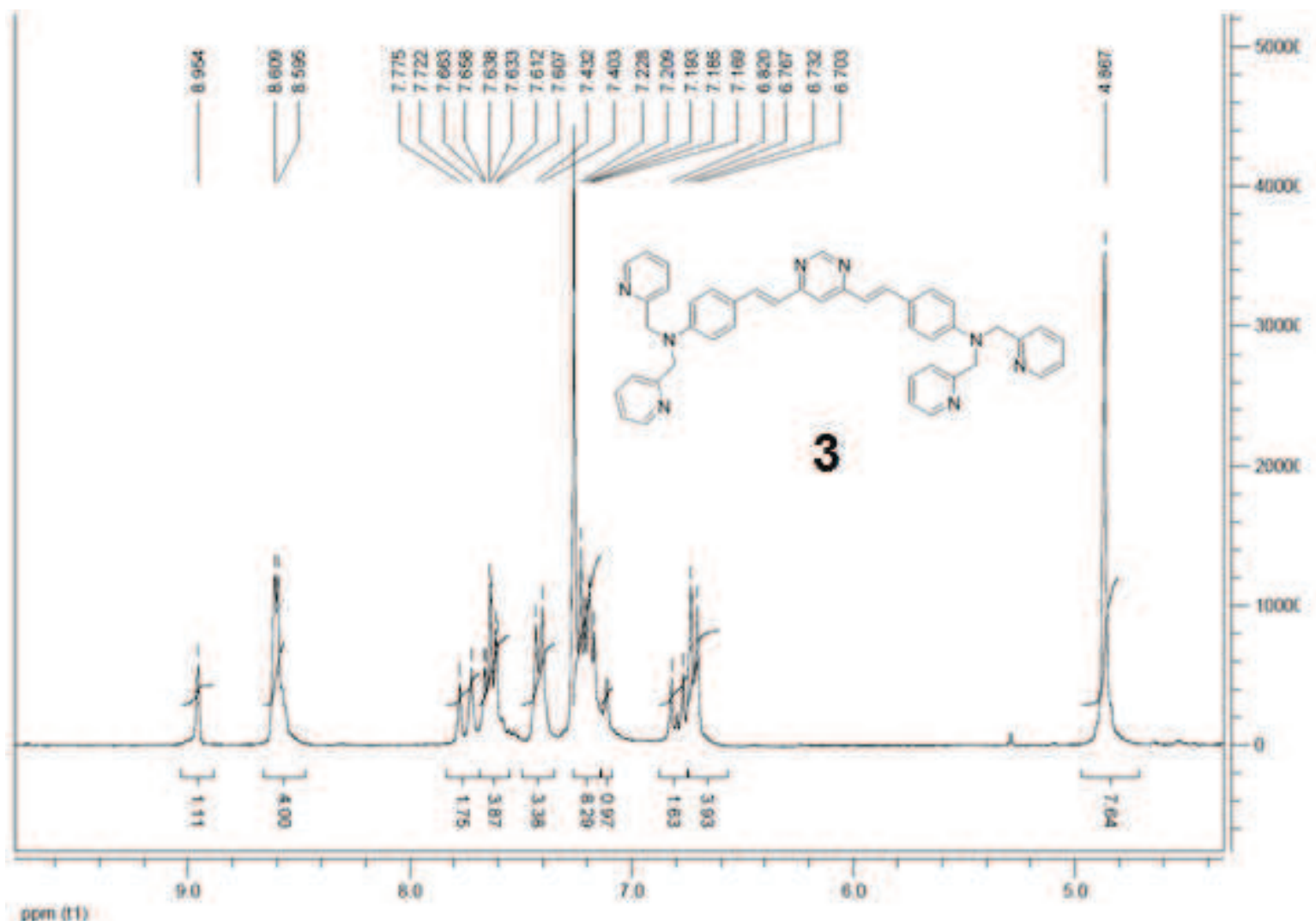

ppen (11)

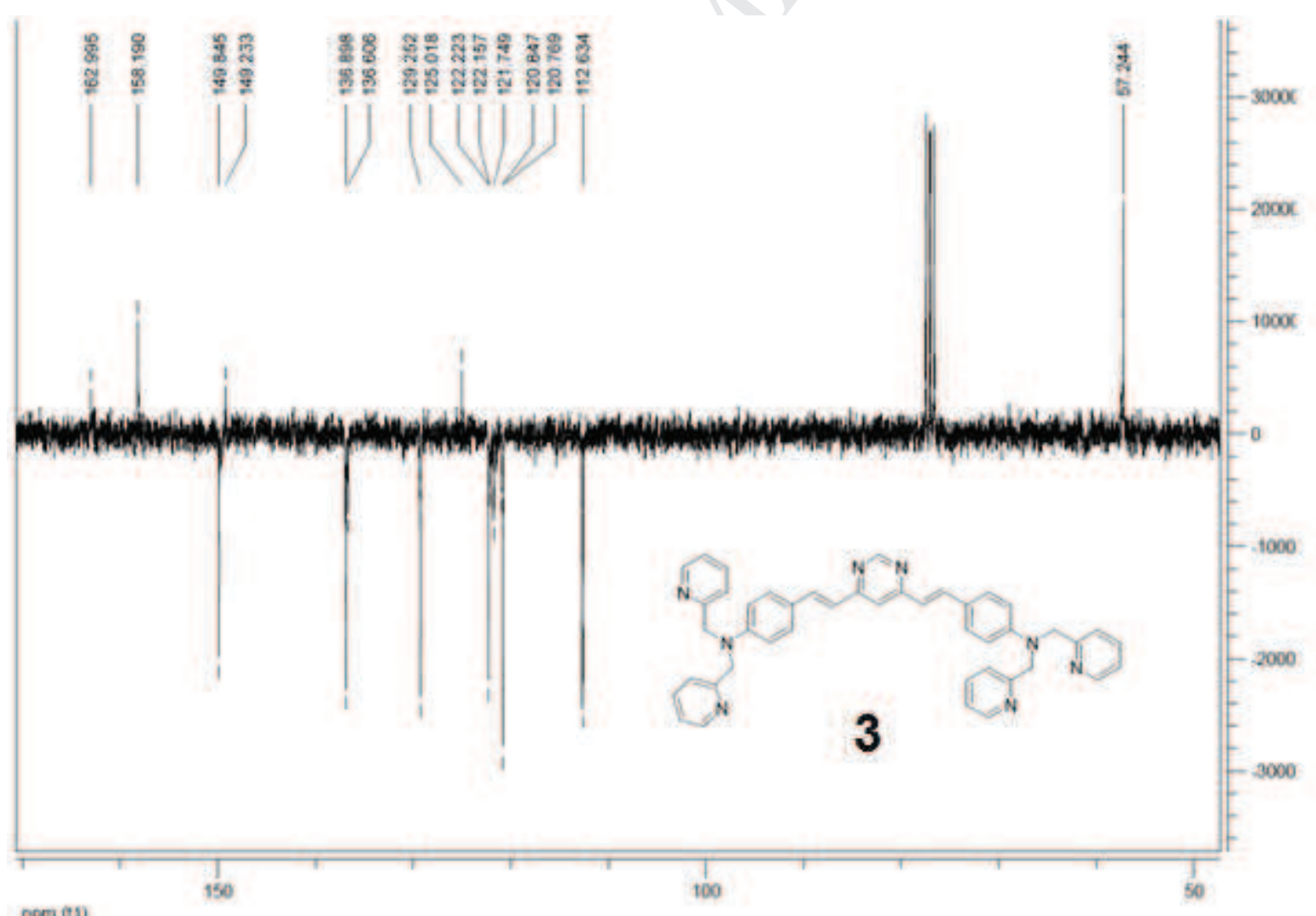



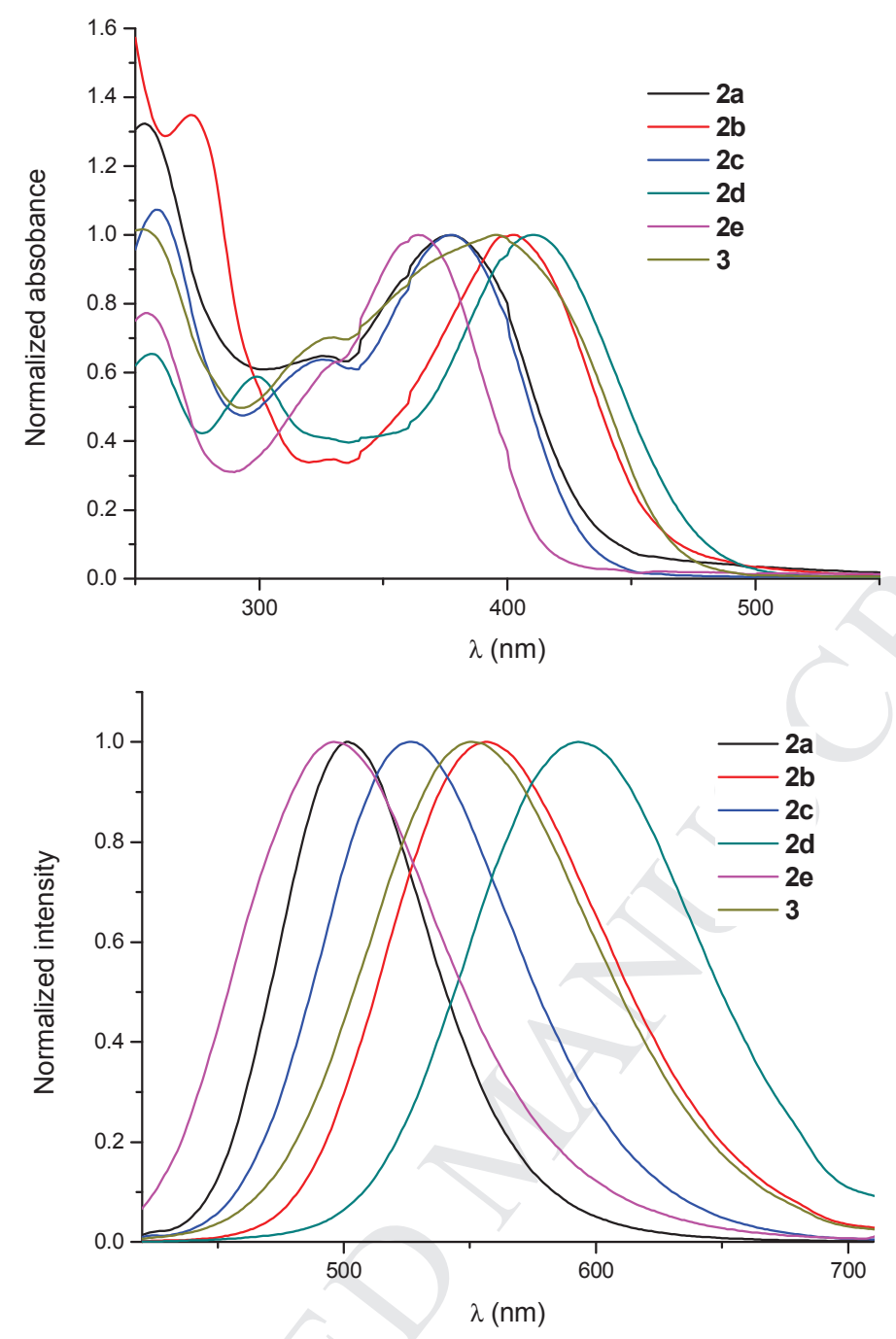

Figure S8. Normalized UV/vis (top) and emission spectra (bottom) of compounds 2a-e and 3 in acetonitrile solution. 


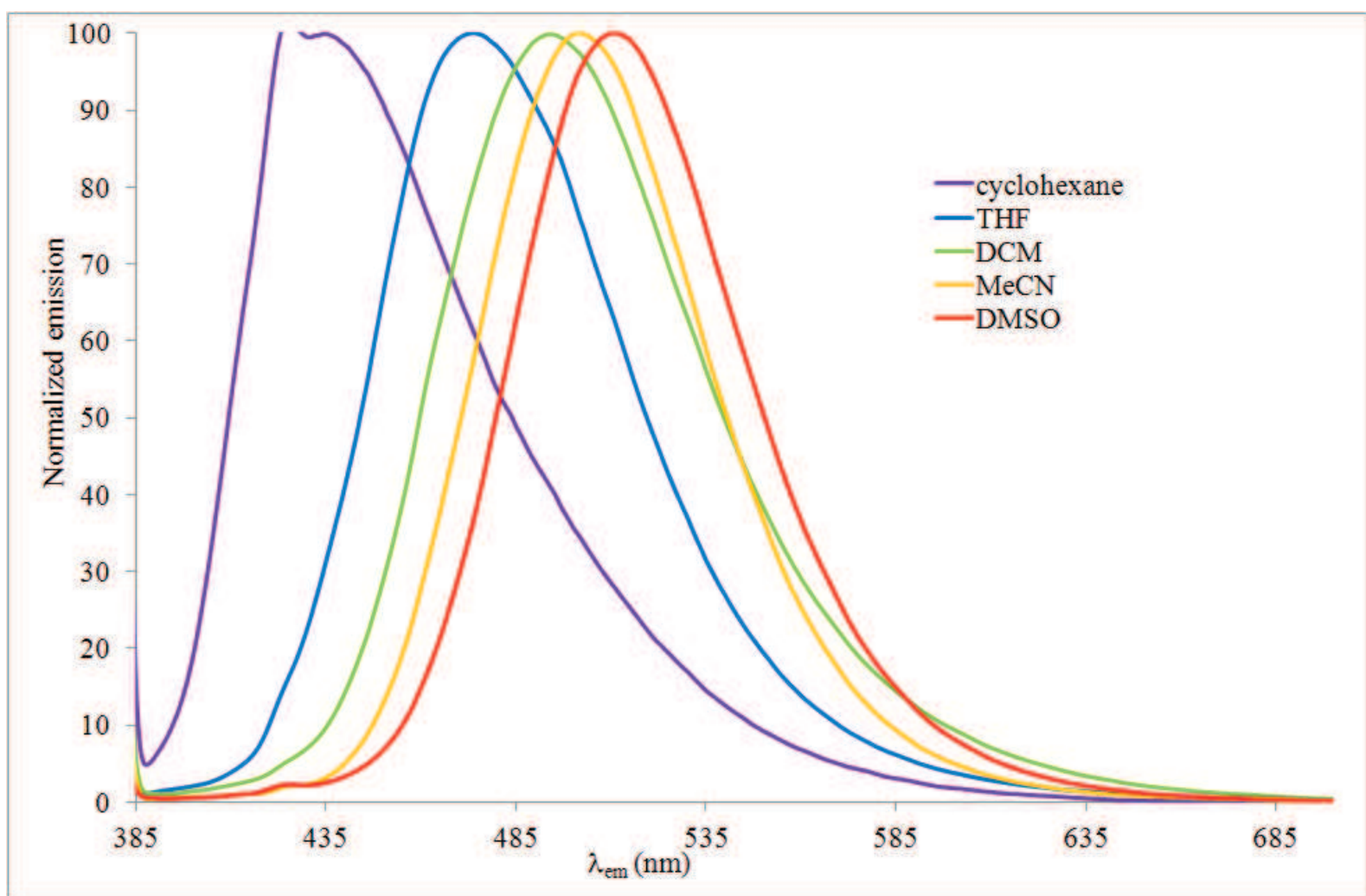

Figure S9. Normalized emission of compound 2a in different aprotic solvents.

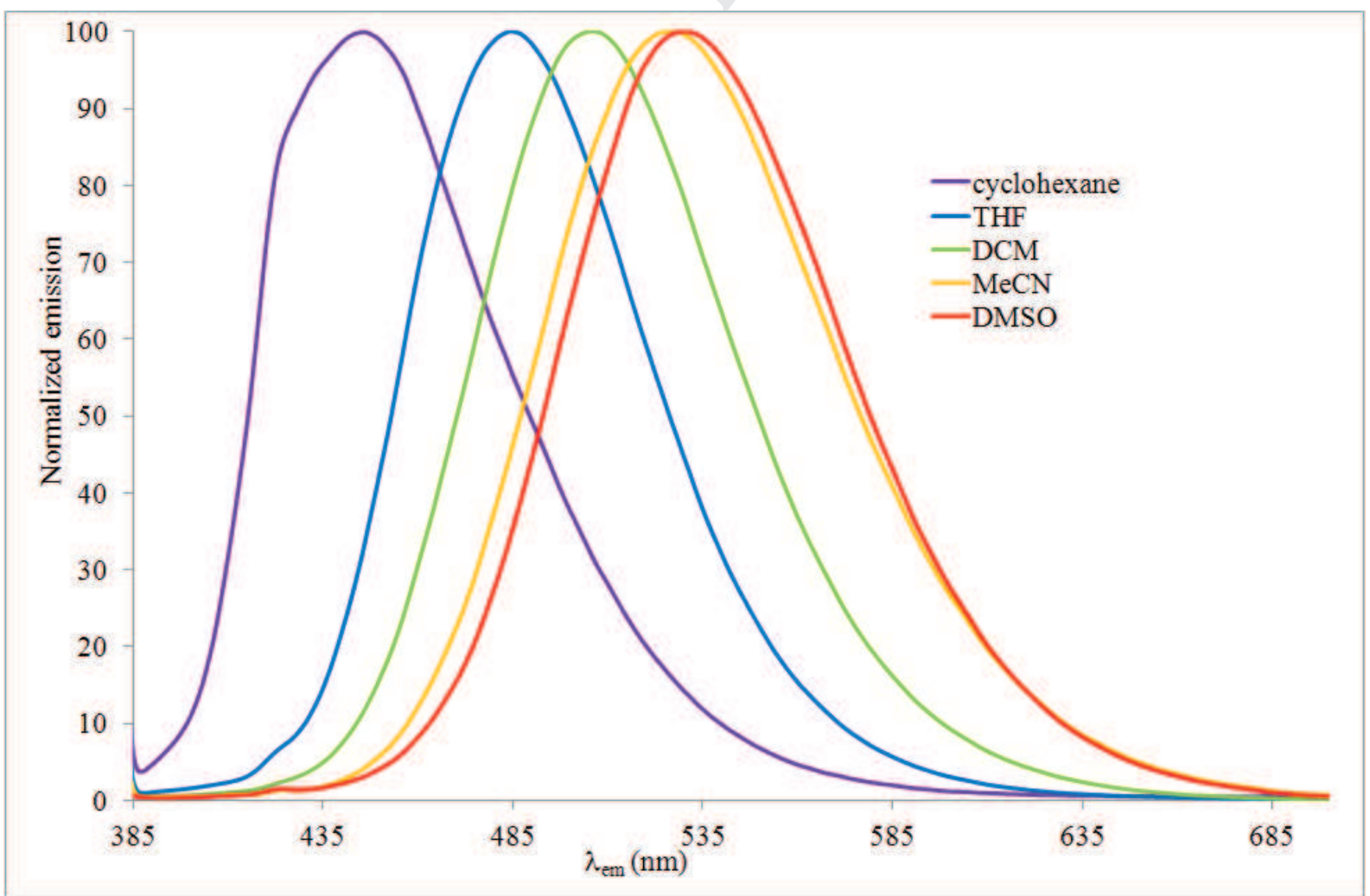

Figure S10. Normalized emission of compound $\mathbf{2 c}$ in different aprotic solvents. 


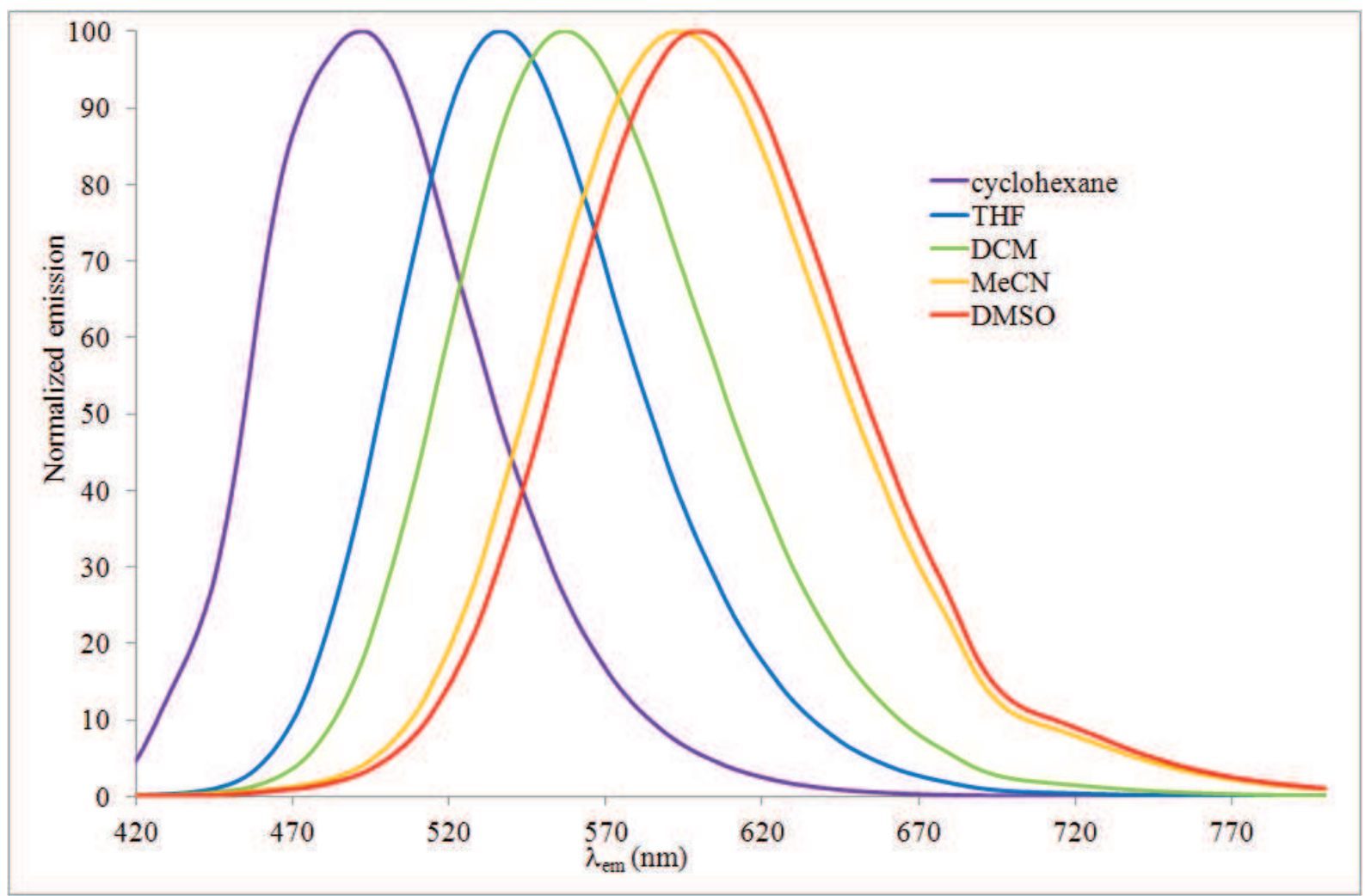

Figure S10. Normalized emission of compound $\mathbf{2 d}$ in different aprotic solvents.

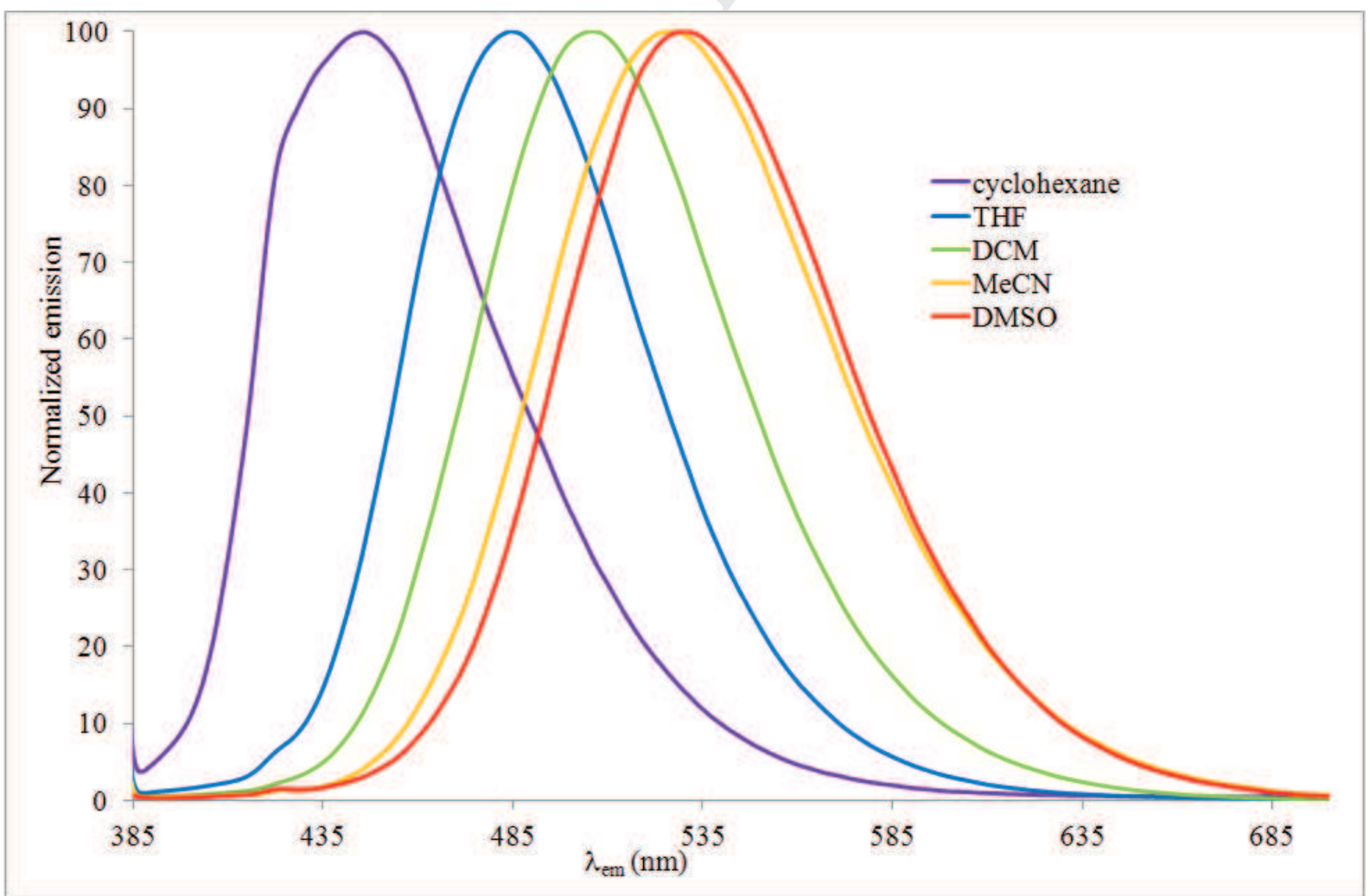

Figure S11. Normalized emission of compound $\mathbf{2} \mathbf{e}$ in different aprotic solvents. 


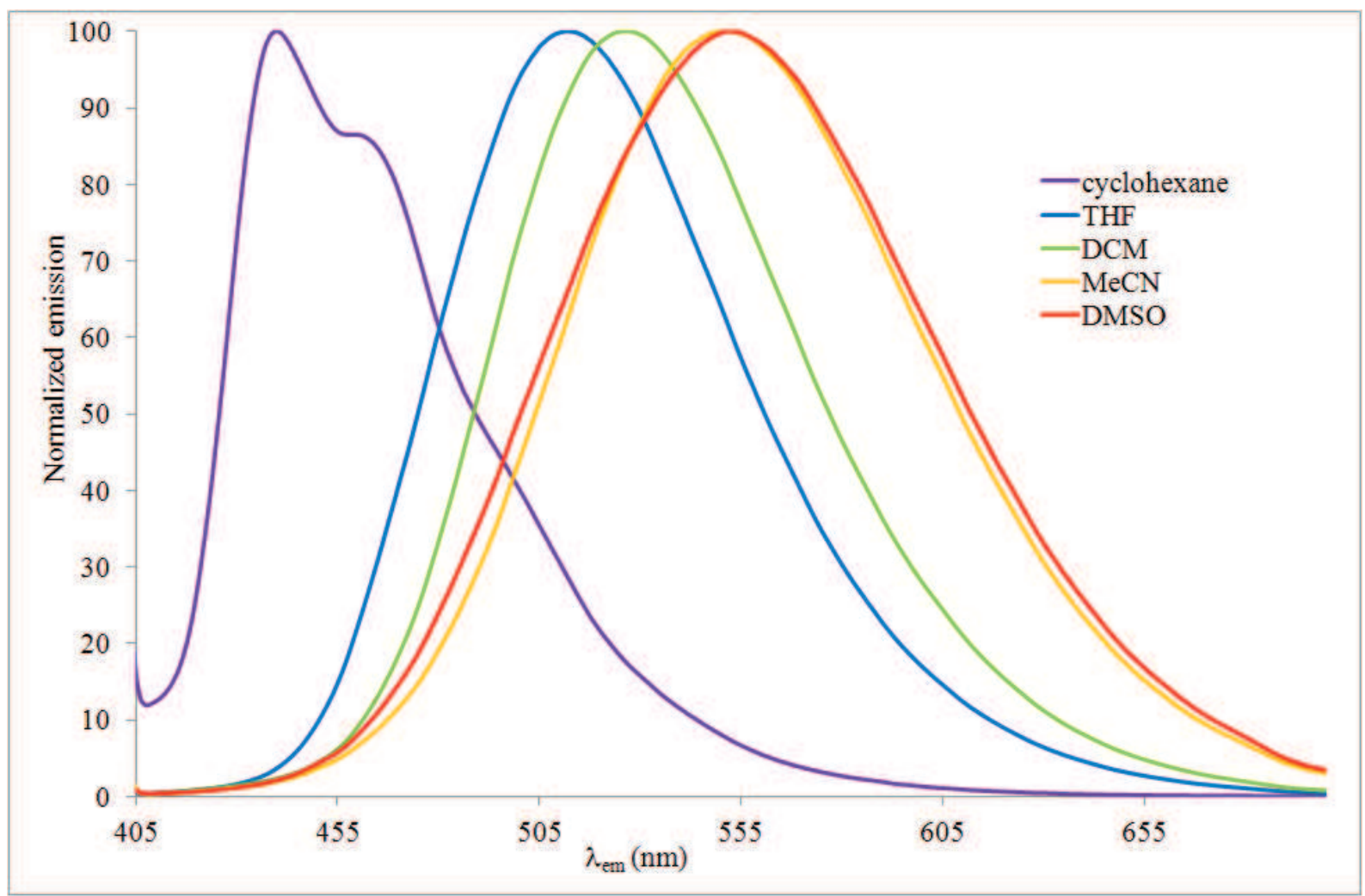

Figure S12. Normalized emission of compound $\mathbf{3}$ in different aprotic solvents.

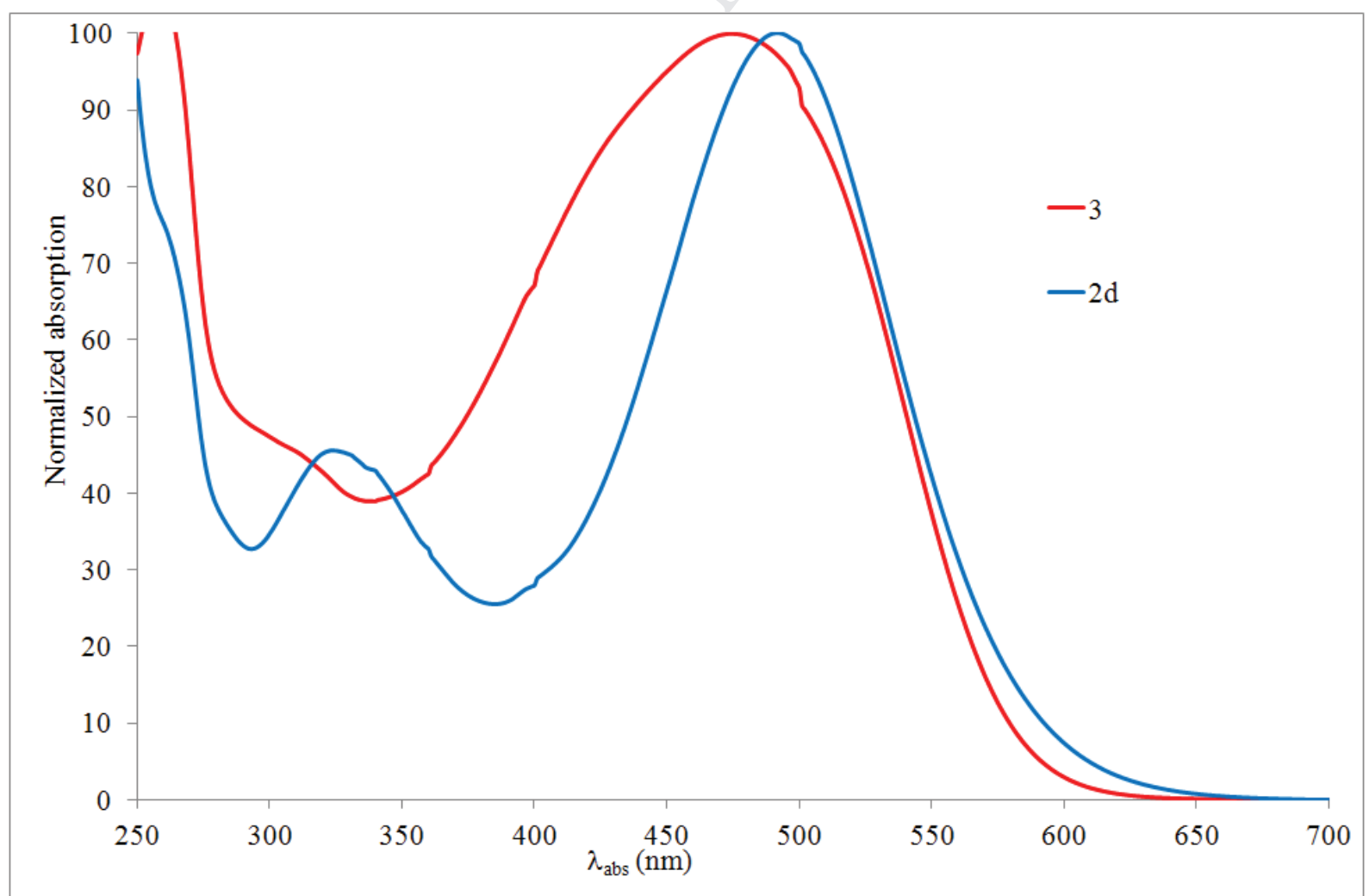

Figure S12. Normalized absorption spectra of compound 2d and 3 in MeCN+TFA . 